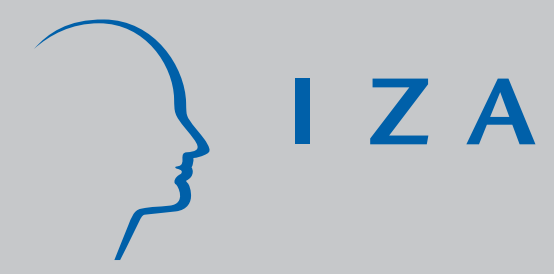

IZA DP No. 2418

\title{
Villages where China's Ethnic Minorities Live
}

\section{Bj orn Gustafsson}

Ding Sai

November 2006 


\title{
Villages where China's Ethnic Minorities Live
}

\author{
Bjorn Gustafsson \\ University of Göteborg \\ and IZA Bonn \\ Ding Sai \\ Chinese Academy of Social Sciences
}

Discussion Paper No. 2418

November 2006

\author{
IZA \\ P.O. Box 7240 \\ 53072 Bonn \\ Germany \\ Phone: +49-228-3894-0 \\ Fax: +49-228-3894-180 \\ E-mail: iza@iza.org
}

Any opinions expressed here are those of the author(s) and not those of the institute. Research disseminated by IZA may include views on policy, but the institute itself takes no institutional policy positions.

The Institute for the Study of Labor (IZA) in Bonn is a local and virtual international research center and a place of communication between science, politics and business. IZA is an independent nonprofit company supported by Deutsche Post World Net. The center is associated with the University of Bonn and offers a stimulating research environment through its research networks, research support, and visitors and doctoral programs. IZA engages in (i) original and internationally competitive research in all fields of labor economics, (ii) development of policy concepts, and (iii) dissemination of research results and concepts to the interested public.

IZA Discussion Papers often represent preliminary work and are circulated to encourage discussion. Citation of such a paper should account for its provisional character. A revised version may be available directly from the author. 
IZA Discussion Paper No. 2418

November 2006

\section{ABSTRACT}

\section{Villages where China's Ethnic Minorities Live}

This paper investigates how ethnic minorities in rural China are faring compared with the ethnic majority. The village is the unit of analysis and large surveys for 2002 are used. Minority villages in northeast China are found to have a somewhat better economic situation than the average majority village, but minority villages in the southwest are clearly faring worse. Industrialisation, inputs in agricultural production, stock of human capital of the labour force, wage level on the local labour market as well as indicators of path dependency are all found to affect the economic situation of a village. Location is the single most important circumstance working against a favourable economic situation for minority villages in the north- and particularly the southwest. Low village income results in long-distance migration for many ethnic minorities, but for some minorities their ethnicity hinders migration.

JEL Classification: J15, O12, P32

Keywords: China, ethnic minorities, income, wealth, migration

Corresponding author:

Bjorn Gustafsson

Department of Social Work

University of Göteborg

P.O. Box 720

SE 40530 Göteborg

Sweden

E-mail: Bjorn.Gustafsson@socwork.gu.se 


\section{Introduction}

The People’s Republic of China now officially recognises the Hahn majority and 55 different ethnic minorities. Most minorities have their own languages. People belonging to a particular minority typically share a common history (an important component of identity) as well as religious beliefs. For example, there are ten minorities usually labelled Muslim. Official recognition of an ethnic minority (minzu) is the outcome of a complex process that mainly took place during the 1950s and involved representatives of the state as well as representatives of the groups being proposed minority status. As a consequence, Hahn includes groups that outsiders would find more different from the Hahn majority than some of the groups now considered a specific minority. Also, when the ethnic categories were institutionalised, they lumped together groups of people who did not necessarily feel they belonged to the same minority.

Officially designated ethnicity plays a vital role in the PRC as each citizen is assigned one of the 56 official ethnicities. Ethnic status is stated on every citizen's official identity card and used for school, legal and official records. Minority persons can benefit from preferential policies, e.g., easier entrance into college and exemption from the more rigid population policy. At the regional and sub-regional level, areas with high concentrations of ethnic minorities have been given special political and administrative status. At the province level there are five Autonomous Regions given special status (Inner Mongolia, Guangxi Zhuang, Tibet, Ningxia Hui and Xinjiang Uygur), 76 autonomous areas at the prefect level and 699 autonomous administrative units at the county level. (China's Yearbook of Ethnic Works, 2003; the information refers to the end of 2002). This administrative structure with elements of self-government makes it possible for different levels of the government to support ethnic minorities with measures by lowering taxes and increasing public expenditures. Further, in minority areas having minority status makes it easier to become a cadre.

Ethnic status thus plays a role in day-to-day life of people living in the PRC as well as in policymaking. Surprisingly little is known, however, on how the 104 million persons making up 8.4 percent of China's population (according to the 2000 Census) are faring in economic terms. ${ }^{1}$ True, much statistical information on autonomous units at different levels can be

\footnotetext{
${ }^{1}$ Collin Mackerras has on several occasions written about the topic. (Mackerras 1994, 1998, 2003). Hannum and Yu (1998) investigated occupation among Hahn and ethnic minorities in Xijniang Uygur Autonomous Region
} 
found, but this information is limited in that the overlap between ethnicity and administrative structure is not perfect. Many minority persons live outside the autonomous areas while certain autonomous areas are inhabited by many majority persons. Actually, in three of the five autonomous regions the Hahn are in the majority; Inner Mongolia is the extreme with a minority population of only 21 percent. At the level of autonomous county there are even examples of a minority share of the population of 10 percent or lower.

This study aims to throw new light on the economic situation of ethnic minorities in rural China by applying an original approach; that of using the village as the unit of analysis. We argue that there are strong arguments for a village level analysis for understanding the economic situation of persons living in rural China. The village is the basic production and social unit for rural people in China. There is also considerable variation in economic conditions across China. Many minority persons in China live in villages with a high concentration of a particular minority. Such villages are concentrated to particular areas of China though very few are found in southeast China. Northeast China has some minority villages while most are situated in the western part of the country.

Our research questions are the following: First, how are different categories of minority villages faring compared with majority villages in rural China? Three criteria are used, average household per capita income, average per capita wealth and villagers' perceptions. Second, which circumstances affect average household income of a village as well as average wealth of a village and how can these circumstances throw light on differences in mean economic situation between different types of minority villages and majority villages? Third, does low village income cause minorities to move out, and to what extent does ethnicity promote or hinder out-migration?

1982 - 1990, Longworth et al (1997) studied pastoral regions, Heberer (2005) entrepreneurship among the Yi / Nuousu ethnic group in Liangshang, Sicuan. Chen Qingde, Pan Shengzhi and Qin Xuemei (2004) studied the characteristics and the dynamics of the economic transition of the ethnic villages. Xincai Gao and Tangwei Teng (2006) analyzed the economic underdevelopment and industry economy of the ethnic region of the Northwest of China. Gustafsson and Li (2003) assessed the ethnic minority - majority income gap in rural China. Using data from 19 provinces for 1988 and 1995 they found that although average income among minorities had increased, the majority / minority income gap had also increased. This was found to be the result of economic growth being spatially unbalanced in combination with China's ethnic minorities living to a larger extent in locations that have experienced below average growth. The same data was also used by Bahalla and Qui (2006) who focused on Southwest China and also studied education, healthcare and anti-poverty policies. 
The database for this study is a survey of more than 900 villages located in 22 provinces in 2002 and a matching survey of households living in the same villages. We define a subset of the villages as "minority villages", the rest as "majority villages". The former are further disaggregated into Manchu villages (all located in the northeast), Uygur villages (all located in Xinjiang), Hui villages (most located in the northwest), and three categories of minority villages located in the southwest: Zhuang villages (all located in Guanxi) Miao villages, Yi villages and a residual category.

The study draws the following conclusions: On average, minority villages in northeast China have a somewhat better economic situation than the average majority villages. In contrast, minority villages situated in the northwest fare worse according to some, but not all indicators. Most troublesome from an equity point of view is that minority villages located in southwest China clearly have a poorer economic situation than the average majority village.

Many circumstances are found to contribute to differences in average household village income as well as household wealth across rural China: the rate of industrialisation, various inputs in agricultural production, the amount of human capital of the labour force, the wage rate at the local labour market and indicators of path dependency. These factors contribute in varying degrees to differences in economic situation between minority villages and majority villages. However, location is found to be the single most important circumstance working against a favourable economic situation for Uygur and Hui villages, and particularly for Zhuang, Miao, Yi and Other southwestern minority villages. We also find that a low village income induces many ethnic minority persons to be involved in long distance migration, but for some minorities this potential source of economic development is thwarted by their ethnicity.

The rest of the paper is organized as follows: The next section defines "minority village", presents the surveys and provides basic information on the different categories of minority villages studied. The economic situation of minority villages is described in Section 3 while Section 4 analyses reasons for why the economic situation at the village level varies and how it can explain the gap between categories of minority villages and majority villages. Outmigration from villages is studied in Section 5 and the paper ends with a section summing up and commenting on the results. 


\section{Surveying, defining and describing minority villages}

This study uses a household survey designed to study the distribution of income and poverty in rural China as well as a matching survey to cadres of the 961 administrative villages located in 120 counties in which the 9200 sampled households were living. Our working sample consists of the 907 villages from which complete information for the variables used in the multivariate analyses were obtained directly from the survey or by filling in missing information from answers to other questions. ${ }^{2}$

The two samples was obtained from the following 22 provinces of China: Beijing, Hebei, Shanxi, Liaoning, Jilin, Jiangsu, Zhejiang, Anhui, Jiangxi, Shandong, Henan, Hubei, Hunan, Guangdong, Guanzi, Chongqing, Sichuan, Guizhou, Ynnan, Shaanxi, Gansu, and Xinjiang. (see Li et al 2006) This information was collected in the spring of 2003 by the National Bureau of Statistics for the reference period of 2002. The households selected constitute a sub-sample of the households surveyed by NBS when producing statistics on household income as reported in the various editions of Statistical Yearbook of China. The survey apparatus of NBS made it possible to collect relatively high quality data in a cost-effective manner. ${ }^{3}$ We are not aware of any previous survey of villages in China possessing the same coverage regarding area and scope. However, the sampling as well as the questions were not primary designed to study the economic situation of minority villages, and for the purpose of this paper the surveys have some limitations which we will now discuss.

First, when selecting province level units the spatial concentration of minorities was not considered. This means that the survey does not include Tibet, Qinghai, Ninxia, Hainan and Inner Mongolia, all of which possess rates of ethnic minority populations higher than for China as a whole. However, all five province level units have (by Chinese standards) small total populations, and not more than 12.0 percent of China's ethnic minority populations live in those five provincial level units.

\footnotetext{
${ }^{2}$ First, we delete the 10 majority village with missing values on average total income. Then, we delete 33 majority villages, 10 Uyghur villages and 1 Manchu village as there was missing data on at least one of the key variables.

${ }^{3}$ Most of the work of designing the village questionnaire was made by Sato Hiroshi, Hitotsubasi University, and draws on his experience from previous geographically more limited surveys as reported in, for example Sato (2003). Sato (2006) matches the village survey with the household survey to study to what extent village characteristics affect household income. This paper differs by using the village as the unit of analysis and to focus on differences between ethnic minority villages and ethnic majority villages.
} 
Second, it should be understood that households, not villages, were selected to be representative at the province level. When collecting household data, NBS uses available documents to survey 10 households stratified by income for each village selected. For our survey this was followed in most, but not all cases. While modifications to this rule were only minor in most provinces, in Xinjiang (with a low population density) only 5 persons in each village were selected. This is the main reason why our sample of villages has a comparatively high fraction of villages situated in Xinjiang. ${ }^{4}$

As there appears to be no previous large scale statistical study of minority villages in China, we have to define at what concentration of minority persons a village qualifies as being labelled a "minority village". According to present law ("Minority Autonomous Township Administrative Work Rules” which was enacted in 1993), a township can apply for Minority Autonomous Township status if the fraction of ethnic minority households accounts for over 30 percent of the total population in the jurisdiction. We therefore decide to classify a village as a minority village when households with a minority person as head comprise at least 30 percent of all households (according to the survey). With this criterion for the 907 villages in our working sample, 151 were classified as minority villages and the rest as majority villages. ${ }^{5}$ The overwhelming number of all minority villages studied here are located in areas that are administered as minority areas. Only 21 villages (14 percent) in Guizhou, Yunnan and Liaoning are located outside such regions.

Information in our surveys makes it possible to further classify minority villages by dominant minority into the six categories Zhuang, Miao, Yi, Manchu, Uygur and Hui. ${ }^{6}$ A seventh residual category includes villages dominated by a particular minority not identified in our questionnaire as well as villages in which it is questionable if one single minority dominates. As background information, Table 1 provides information on the ten ethnic minorities with the largest populations in rural China as well as the urbanisation rate for each. With the exception of the Tuija, our study identifies the largest ethnic minorities in rural China.

\section{/Table 1 about here/}

\footnotetext{
${ }^{4}$ In our sample is the number of households roughly proportional to the population size but can deviate due to for example rounding of the number of households chosen.

${ }^{5}$ Increasing the cut-of point up to 50 percent would decrease the number of minority villages by not more than 22, while lowering the cut-of point to 20 percent would increase the number of villages by only 11 .

${ }^{6}$ Following the practice in many official documents for the PRC, in this paper we use Mandarin names of the minorities. Several minorities, however, prefer to use names in their own languages, see Table 1.
} 
Table 1 also shows that out of the six minorities covered the Hui is the smallest with 5.4 million rural inhabitants. Still, the rural Hui are more numerous than the rural Tibetan, Mongolian and Dong minorities not identified in this study. In addition, the Hui live in cities to a larger extent than the rest of the population in China while the urbanization rate for several of China's other larger minorities is fairly low. The extreme in this case is the Yi with an urbanisation rate of only 10 percent.

\section{/Table 2 about here/}

Of the six minorities identified here, the Manchu is the only minority situated in northeast China. Table 2, where we list types of minority villages along with majority villages in each province of the survey, shows that 19 of the 20 Manchu villages in our sample are situated in Liaoning. A larger number of minority villages are found in Xinjiang where all of the 50 Uugur villages are situated and most of the Hui villages. In our survey as many as 61 minority villages are located in the southwestern provinces. There are 16 Zhuang villages concentrated to Guanxi while the numbers of Yi villages and Miao villages situated in more than one single province is smaller. Thirty-one of the 35 minority villages belonging to the residual category are situated in the southwest.

\section{/ Table 3 about here./}

From the village questionnaire, Table 3 provides basic information on the seven categories of minority villages as well as the majority villages. There are great differences across minorities regarding altitude; the southwestern minorities live predominately on mountains or hilly areas while the Uygur villages are all situated on plains. Manchu villages appear to have been in contact with the outer world longer than the average majority village as indicated by year of electrification. Further, at the time of the survey all Manchu villages were close to transport facilities like a bus terminal or a train station. In contrast, the Yi villages received electricity later and villagers still need to walk long distances to find transport. Zhuang villagers and people in Other Southwestern Minority Villages live secluded from the political and administrative centre of the county. 
Table 3 shows large variations in population size with the average Zhuang village having almost three times as large a population as the average Uygur or Miao village. Turning to our focus, the economic situation, it can be noted that all Miao villages, all Yi villages and most Zhuang and Southwestern Minority Villages are situated in areas classified as poor, and are therefore subject to particular policy measures. In contrast, not a single Manchu village is located in such an area.

\section{Economic situation in the villages}

When assessing a village's economic situation we will use three different criteria to provide a more comprehensive picture. Table 4 reports per capita income based on information from the village questionnaire using the same definition as that used in official statistics. ${ }^{7}$ In addition, to report mean values for each type of minority village we have classified all sample villages into deciles with those with the lowest income in the first decile, and those with the highest in the top.

\section{/ Table 4 about here./}

We find that Manchu villages fare better compared to majority villages and mean income is one-third higher. All Manchu villages are in the upper half of the income distribution, although they are not overrepresented in the very highest decile. The northwestern minorities have a somewhat lower average village income than the majority. For Hui villages the income gap is 20 percent and for Uygur villages 32 percent. Uygur villages are overrepresented in the bottom of the income distribution, but can be found in all deciles with the exception of the top decile. An important finding is that all four categories of southwestern minorities have low average per capita income. The average income gap is about 50 percent and actually all Zhuang, Miao and Yi villages are located in the four lowest deciles of the income distribution. Table 4 also shows that out of the villages in the bottom decile, 41 are minority villages and 49 are majority villages. In contrast, in the top decile all but two Manchu villages are villages inhabited by Hahn.

\footnotetext{
${ }^{7}$ This mean money income in included as well as income from subsistence production but not imputed income from owner occupied housing.
} 
It is unusual to find good quality information on household wealth in low-income and middleincome countries. However, for rural China there is a series of previous wealth studies to benefit from when defining and measuring household wealth. ${ }^{8}$ We follow the most recent when defining the five components of wealth; user rights of land, financial assets, housing, consumer goods and capital assets (including the value of livestock as well as machinery and constructions used for production). Summing the components and deducting debts we arrive at net wealth. This information is taken from the household questionnaire; we assign it to villages and report the results in Table 5, which also shows how different categories of minority villages are located in the wealth distribution.

\section{/Table 5 about here/}

As affluent villagers are better able to accumulate wealth one would expect to find that information on total mean wealth would be similar to information on mean income for the focus of our study, minority villages. This is also what Table 5 shows. ${ }^{9}$ Manchu villages are reported to have 42 percent higher mean per capita wealth than majority villages, while mean wealth in Hui and Uygur villages are 15 percent below the mean income for majority villages. Minority villages in the southwest have mean wealth only about half as high as for majority villages. Table 5 also shows that among villages in the bottom of the wealth distribution, 31 are minority villages while 60 are majority villages. In the top decile only four Manchu villages and two Uygur villages are found.

When inspecting the composition of wealth components for the various categories some differences are worth noting. The differences indicate differences in production structure across categories and perhaps also ethnic differences in prioritising consumption levels today and tomorrow, which can be thought to be linked to risk behaviour. Manchu villages are particularly rich in financial assets, but only marginally richer than majority villages in consumer durables and housing wealth. This could signal that Manchu people are more cautious than the majority. Hui villages as well as Uigur villages are richer than majority villages in user-rights to land as well as of capital assets, in which the value of livestock is included. This reflects the importance of pastoral production; living as a nomad makes

\footnotetext{
${ }^{8}$ McKinley (1996) who analysed household wealth in 1988, Brenner (2001) who studied household wealth in 1995 and Zhao and Ding (2006) who studied household wealth in 2002.

${ }^{9}$ The correlation coefficient is equal to 0.710 . However, the relation is not linear as shown when regressing total per capita wealth on total per capita income and its square, as coefficients for both these variables are positive and estimated with high t-statistics.
} 
spending on housing and consumer durables difficult. At the same time these villages are poorer than the majority also regarding financial wealth, which indicates that livestock is a substitute for cash. In contrast we do not find significant differences in the composition of wealth between the four categories of ethnic minority villages located in the southwest on the one hand and the majority villages on the other. The four categories of minorities are poorer than the majority in all components, and this is particularly true for financial assets. This information suggests that minorities living in the southwest, particularly the Miao and the Zhuang, should be vulnerable to external shocks. This is in contrast to the Manchu villages. Generally speaking, households in rural China have few debts, a consequence of an underdeveloped capital market.

To what extent are the differences in economic situation across various types of villages reported here perceived by their inhabitants? Given that China is a very large country with the villages often spatially widespread, and given that communication is not very well developed, the answer is not self evident. One can surmise that minority people living in the southwest although objectively poorer than their counterparts elsewhere, are not necessarily less satisfied with their lot.

\section{/Table 6 about here/}

The household survey gives a unique opportunity for studying the villagers' perception of economic situation and also how it agrees with the objective criteria. We aggregate answers on four differently phrased questions along with one on adult self-reported health from the household questionnaire to the village level. We then compute mean values for each category of minority village and test if they are statistically different to the majority village. Interestingly enough, Table 6 shows a similar overall ranking of village categories as the information based on income and for total wealth, although the pattern does not show up in the answer to each separate question and for each particular type of village.

Manchu villagers are on average more satisfied then the average majority villager according to answers to two of the four questions. With only few exceptions do all indicators show minority villagers in the southwest to be less satisfied with their economic situation than the majority. In addition there are indications of villagers in the southwest having worse health. 
Only among minority villagers in the northwest does the perception of economic situation not clearly differ from what is calculated for the majority population. ${ }^{10}$

In this section we have shown that different minority villages have rather different economic situations with the southwestern villagers being worse off, and the northeastern minorities having a situation better than the majority. The situation for minority villages located in the northwest falls between these two poles; according to the level of average household income, average household financial wealth, and possession of consumer durables, they are worse off then the majority. However, regarding user-rights to land and capital assets they are more affluent than the majority; there are no clear indications that they perceive themselves to be worse off than the majority. What are the reasons for the differences across categories of villages we have shown? This is the topic for the next section.

\section{Understanding the economic situation in the villages}

Many researchers have studied why provinces in China differ in income while others have studied why household income in China varies. In contrast there has been little research on why villages differ in economic situation. ${ }^{11}$ The analysis in this section is laid out as follows. First a number of variables aiming to map important circumstances are extracted from the village survey and used to show the variation with all villages in the work sample as ranked by mean income into deciles. Second, expecting many circumstances to be of importance, regression models are estimated using income per capita alternatively household per capita wealth as the dependent variables. In a third step these estimates together with observed mean values for the different categories of villages are used to predict mean income and mean wealth, respectively. The predictions are made for the various categories of villages under various assumptions in order to better why mean income and mean wealth vary across

\footnotetext{
${ }^{10}$ The results for Uygur villages are contradictory as on average the villagers indicate they are more satisfied than the majority with income of their household, but less satisfied when it comes to food supply and also money adequacy. Out of various possible explanations for this result one is that it is simply due to survey limitations. The questions were formulated in Mandarin which is not the first language of several respondents.

${ }^{11}$ One exception is Knight and Li (1997) who studied income differences across seven villages in Hadan county, Hebei 1994. Note that here we observe income levels at one point in time. These are the results of growth processes that have taken place in various villages. The growth process is best understood if analysing panel data. Panel data would also make it possible to investigate if ethnic diversity affects economic growth. There is new literature asking this question that uses country data and another using sub-national data for the United States, see Alesina and La Ferrara (2005).
} 
categories. The final step, to analyse out-migration from the village, is reported in the next section.

/Figure 1 about here/

To what extent can a relation between how early villages were opened up to the outer world and village income in 2002 be revealed? We use the year when electricity was introduced to the village as an indicator and report the relation in the upper part of Figure 1. It shows that villages that were electrified before 1969 make up two-thirds of the villages in the top decile. At the other end of the spectrum, one can note that no village that received electricity during the 90s belongs to the top income decile. The second part of Figure 1 shows clear relations between village altitude and village income. Most villages in the top of the income distribution are situated on plains, while villages located on mountains are concentrated to the three lowest deciles. $^{12}$

History shows many examples of economic growth being a consequence of industrialisation. Calculated over all villages in our survey, only 5 percent of the population is engaged in manufacturing and an additional 4 percent in construction. Particularly the first is not a large number. However, Figure 1 shows a much higher rate of the population in manufacturing in villages in the top income decile. The figure also shows a positive relation between the rate of the population in construction and income.

Another road to economic growth is high and sustained agricultural production. Our data is rich in variables measuring inputs into agricultural production and all variables extracted show positive relations with mean village income. However, the relation is not always linear over the entire income distribution. While the size of irrigated land doubles from decile 2 to decile 8 in the income distribution of villages, it actually dips at the top decile meaning that land abundance is not the key to top income. There is not much of a relation between area used for planting vegetables and income at the bottom and in the middle of the income distribution, but in the upper part the relation is steep. This indicates that specialising in growing a high value commercial crop is an alternative strategy to industrialisation for procuring a top income. Further we find that villages in the upper part of the income

\footnotetext{
${ }^{12}$ An altitude of less than 200 meters above sea level is termed "the plains", an altitude of 200-500 meters above sea level is classified as "hills" and "mountains" areas have an altitude of more than 500 meters above sea level.
} 
distribution have comparatively high productive village fixed assets, while those in the lower part have almost none. Villages in the bottom of the income distribution are characterised by a high rate of natural disasters.

There is a clear positive relation between average education in the adult village population and village income with a difference of about 1.5 years of schooling between the lowest and the highest income decile. In our sample the daily wage for a temporary worker is18 Yuan. The daily wage is 15 Yuan in the lowest of the income deciles and almost 25 Yuan in the highest income decile. Finally we notice that villages in the top of the income distribution are situated in provinces with mean incomes twice as high as those in the first seven deciles. High provincial income means high demand for agricultural products and labour compared to low provincial income.

\section{/Table 7 about here./}

To what extent do the relations shown in the bivariate analysis also emerge in a multivariate analysis? The results from estimating linear regression models by OLS are reported in Table 7 where the same specification is used to analyse average household village income and average household village wealth. Generally the coefficients in the wealth function are much larger than those in the income function, which is as one would expect when wealth is the consequence of accumulation of household income. Also generally we find that most of the relations uncovered in the bivariate relation are present in the multivariate analysis; we direct our comments to the exceptions.

First, we note no significant coefficient for the population share engaged in construction on income and actually a negative coefficient for the wealth function. One possible reason for this is that poor economic opportunities cause villagers to specialise in construction (as migrant workers for example), so causality does not run the way we postulated when estimating the functions. Second, the coefficient for village fixed assets in the income function (but not in the wealth function) is estimated with a t-statistic that is not particularly high. This could signal that investments are not efficiently allocated across villages, which is not surprising as rural China more or less lacks a capital market. Another possible reason is that our estimated equation does not include the households' own investments in fixed assets. The occurrence of disasters in 2002 is found to affect average household income but not 
average household wealth. This is plausible if disasters occur more or less at random at the village level. Fourth, while availability of electricity before 1969 is shown to have an effect on village income as well as average household village wealth in 2002 according to the estimates, this timing of opening up the village to the outer world is not found to have an independent effect on village economic situation in 2002. Our model might thus capture most relevant factors affecting the village's economic situation, with the exception of the benefits from comparatively early development.

\section{/Table 8 about here/}

Equipped with the results from the analysis we now look at how the different categories of minority villages are endowed with income and wealth generating factors, see Table 8 . All categories of minority villages, including the more prosperous Manchu, have rates lower or much lower than the majority of the population occupied in manufacturing. The Hui and the Uygur villages have access to larger plots of irrigated land than the majority villages which is in contrast to the minority villages situated in the southwest. Manchu villages are better off than the majority villages in many circumstances: larger areas planted with vegetables, more productive fixed assets and a population with longer educations. In addition, the daily wage at the local labour market is slightly above that for majority villages as is provincial income. In contrast, the minorities living in the southwest cultivate small areas to for growing vegetables, have lower than average educations, meet low daily wages at the local labour market and have experienced a high frequencies of natural disasters. Further, southwestern minority villages are situated in provinces with below average income.

Based on the mean values for each minority category we predict their average income. Most predictions are reasonably close to the observed values, see Table $9 .{ }^{13}$ Based on the predictions we simulate mean per capita household income and mean household wealth for the various categories. This is done under various scenarios by changing the mean value of each explanatory variable to the mean of the entire sample. This exercise makes it possible to quantify reasons for why a specific minority category has an economic situation different from the majority. It turns out that results for average household village income and average

\footnotetext{
${ }^{13}$ The largest discrepancy are for wealth among Yi villages (only 62 percent of observed value) and Manchu villages where we under-predict mean income by 14 percent and mean wealth by 18 percent (although those predictions are correct in being higher than for the majority villages).
} 
household village wealth are rather similar. We find that some of the factors contributing to southwestern minorities having comparatively low mean income and mean wealth are not trivial. For example if the labour force engaged in manufacturing within the Zhuang and Yi villages would be brought up to the national average, average village income would increase by 11 and 22 percent, respectively. Increasing education among the Miao and the Yi to the national average would increase average village income by 10 and 17 percent, respectively.

\section{/ Table 9 about here /}

However, by far the most critical factor for explaining why village income and village wealth are low among minority villages in the southwest is location as measured by altitude and mean provincial income. This signals the existence of important spillover effects from the broader environment to the village and that economic opportunities in present day China are rather unevenly distributed over the country. Table 9 shows a simulation where altitude as well provincial mean income are both brought to the country mean. Under such assumptions, mean village income in Hui villages and Uygur villages would rise by about 20 percent (while average household village wealth would be only marginally affected). This would completely close the gap in income between Hui villages and the majority villages and erode most of the income gap between Uygur villages and Hahn villages. Turning to the minorities in the southwest, we find that a hypothetical relocation to the same altitude and province income as the majority is rather important for increasing income and wealth. Most noticeably, mean income in Miao villages would increase by not less than 66 percent and in Yi villages mean income would almost double. Nonetheless, we must remember that although considerable, such changes are not sufficient to fully erode the gap between the ethnic majority and the minorities.

\section{Out-migration}

A rather important force set in motion by China's economic development and also contributing to it is internal migration. People seeking better incomes move from rural areas with a large labour surplus to urban areas. The urban to rural income gap is rather large and has remained large for some time. Much of the rural to urban migration is temporary, partly due to the difficulty for people without urban residence permits in finding housing and social 
services for themselves and their families. Households in China are well known for saving a high proportion of their income; rural to urban migrants save even higher proportions of their income. Such resources can increase household consumption in the village of origin, be invested in housing or in productive activities. There is thus potential for dynamic benefit of internal migration for economic growth at the origin. The benefits may only be deemed potential as nothing guarantees that income generated by migrants must feed back to the village of origin.

From the fact that they are economically more disadvantaged than the ethnic majority, one would expect that most of China's ethnic minorities would more often migrate internally than the majority. Migration could thus function as an equaliser of living conditions between the majority and the minority. However, the story of ethnic minority migration is more complicated than this. Income is not the only argument in the household's utility function. Persons can also place a positive value (which can be large), on the capacity of practicing ethnic habits and living with persons from the same ethnic group. This can dampen migration of ethnic minorities, which is also the case if the minority persons have not yet mastered the predominant language at the destination (Mandarin) and therefore face difficulties in finding well-paid jobs.. Ethnic minorities may also be discriminated against at the potential destination. If such mechanisms are at play, ethnic minorities with strong cultural identities who are easy to differentiate from others can be expected to be less likely to migrate than majority persons living in villages with the same economic situations. However, it is also possible to think of ethnicity as contributing to migration if migration becomes the norm in the ethnic group to a larger extent than in the majority. What do our data tell us about ethnicity and migration in rural China? ${ }^{14}$

\section{/ Figure 2 about here/}

From the village survey we can compute the ratio of migrants working out of township more than six months (short distance migration) and the ratio of out-migrants working out of province (long migration). These variables (migration rates) can be computed for 1998 as well as for 2002. Figure 2 shows that the two migration rates increased from 1998 to 2002 which is

\footnotetext{
${ }^{14}$ Based on 1990 Census data, Iredal (2001, p 105) finds relatively similar rates of movement among Hahn and minorities (considered as one category) within provinces, but lower rates of minority movement across boundaries.
} 
consistent with what Du et al (2005) report from a large sample of households living in poor areas 1997 to 2001. There is a difference regarding the bivariate relation between average village income and migration rates. While there is not much of a relation in the case of short distance migration, the effect is noticeable for long distance migration. In particular, villages in the second, third and fourth deciles of the income distribution at the origin have sent many migrants out of the province.

/ Table 10 about here.

Table 10 reports that some minority villages have migration rates higher than the majority, while others have lower. Miao and for 2002 Zhuang belong to the group of high migration rates, while Manchu, Hui, Uygur and Yi belong to the latter category. The variation between the extremes is large as only 1 percent of the Uygur villagers were involved in migration (short distance or long distance) in 2002 compared to as many as 19 percent of the Zhuang. But to what extent are these differences generated by differences in economic situation and other factors affecting migration, and to what extent are they caused by ethnicity alone?

In order to investigate the role of ethnicity for out-migration from villages we estimate regression models with a number of dummy-variables indicating ethnicity as explanatory variables. We apply the same specification to explain short distance migration and long distance migration in 2002 making it possible to find out to what extent determinants agree or differ. Control variables include average village income in 1998, average province income in 1998, and average irrigated land per capita. Further we include two dummies measuring altitude and dummies for when the village received electricity to capture to what extent migration flows are influenced by historical factors. The village questionnaire also includes some questions aimed to map social capital at the village level and we use three of those.

\section{/ Table 11 about here/}

Starting with coefficients for the control variables we find that some affect short migration and long migration similarly, see Table 11. This is the case for the negative effect of village income, the negative effect of the village being electrified before 1969 and the positive effect of the social capital variable that measures the frequency of villagers exchanging information on employment. Some coefficients are estimated with high t-statistics and of expected sign in 
one of the equations but not in the other. Short distance migration is found to be positively affected by average province income (possibly a pull factor) and altitude, and negatively by two indicators of social capital at the village level. In contrast, the negative coefficient for per capita area of irrigated land is estimated with a high t-statistic only in the equation explaining long distance migration. Ownership of land thus seems to dampen long distance migration, but not short distance migration.

Turning to the coefficients for ethnicity we find the clearest result for Uygur as relatively large negative coefficients are estimated with a high t-statistics in both equations. In addition there are two other examples of negative coefficients for ethnicity estimated with relatively high t-statistics. This is the case for Yi in the equation of long distance migration, and for the Manchu in the equation for short distance migration. The positive effect of Miao ethnicity in the equation for long migration is estimated with a t-statistic just below 2.0. Why do indications of Uygur ethnicity negatively affect out-migration so much more clearly than for other ethnic groups? One possible reason could be that our sample contains many more Uygur villages than villages inhabited by other minorities. However, just as plausible an explanation might be that the Uygur ethnic identity is rather strong. Uygur people typically differ from the majority in language, religious beliefs and appearance more than the other minorities studied here. $^{15}$

\section{Conclusions}

This paper has investigated how ethnic minorities in rural China are faring by comparing them with the ethnic majority using the administrative village as unit of analysis. We have studied 907 villages located in 22 provinces using information from a village survey to cadres, and from a household survey. Villages with a minority share of at least 30 percent were classified as minority villages and further dissagregated into villages mainly inhabited by Manchu, Uygur, Hui, Zhuang, Yi and Miao minorities and a residual category. The economic situations in the various categories of minority villages and in majority villages were investigated using information on average household income, average household wealth and the perception of villagers.

\footnotetext{
${ }^{15}$ For a fuller discussion of ethnicity and Uygur migration see $\mathrm{Hu}$ (2003) who studied Uygur movement within Xinjiang and Hoy and Qiang (2003) who investigated Uygur migration to Beijing.
} 
The study shows that minority villages located in the northwest, the Manchu villages, are on average faring better than the majority villages. In contrast, minority villages located in the southeast, the Zhuang, Yi, Miao and Other Southwestern Minority villages, are clearly faring worse according to all criteria applied; a finding troublesome from an equity perspective. The economic situation for minority villages located in the northwest, Uygur villages and Hui villages, falls between these polar cases. According to the levels of average household income, average household financial wealth and consumer durables, they are more disadvantaged than the majority. However, when viewing user-rights to land and capital assets, they are richer; there are no clear indications that they perceive themselves as having a worse situation than the ethnic majority.

The study has shown that many circumstances affect mean household village income as well as mean household village wealth. A large proportion of the population in manufacturing signifies a high chance that the village has a high income. Different input or conditions for agricultural production affect village mean income positively. Some of these, such as natural disasters, are important for belonging to the lower part of the income distribution of villages. Others, such as possession of a large area used for vegetable production, are important for being in the top of the distribution. There is a positive relation between education among adult villagers and the prevailing wage rate in the local labour market on one hand and on village average household income and village household wealth on the other. Villages that were electrified earlier are more likely to have good economic situations in 2002 than other villages, even after controlling for other factors.

Although the regression analysis showed that factors affecting household income and household wealth are many, location as measured by altitude and province income was found to be rather important for explaining the low income and wealth among minority villages in southwest of China and the relatively low income and wealth among villages in northwest China. Particularly we found that location disfavours Miao villages and Yi villages, although location alone cannot fully explain the low village income for these minorities.

Out-migration can function as a mechanism for economic development in minority villages as well as in majority villages. We found that migration rates at the village level have increased over time and this is true for short-distance as well as long-distance migration. There is 
significant variation in migration rates across minorities; fairly low migration rates for northwestern minorities and high migration rates for southwestern minorities. It was found that many factors affect migration rates, and to some extent the high migration rates observed for southwestern migrants are due to factors such as low village income and altitude. The clearest indication of ethnicity having an independent and negative effect on geographic mobility was obtained for the Uygur villages. While out-migration seems to have the potential to narrow the income gap between southwestern minorities and the majority, it seems less likely to be true for Uygur minorities.

This study has focused on rural China, home to most minorities, while the economic situation of the rapidly increasing number of minorities living in urban China has not been investigated. Although we have covered six of the seven largest minorities in rural China, not less than 49 other minorities remain to be investigated. Focusing on circumstances in 2002 provides a reasonably up-to-date picture, but changes over time remain to be analysed. These are but a few of the limitations of this study, indicating that more effort to investigate the economic situation of ethnic minorities in China is motivated.

\section{Acknowledgement}

This study was made possible by financial support from the Swedish Development Agency (Sida), Ford Foundation and Japan Society for the Promotion of Science (JSPS) and the Masayoshi Ohira Memoria Foundation. 


\section{References}

Alesina, Alberto and La Ferrara, Eliana (2005) "Ethnic Diversity and Economic Performance”, Journal of Economic Literature, XLIII, 762 - 800.

Bahalla, A. and Qui, S. (2006) Poverty and Inequality among Chinese Minorities, London and New York: Routledge (Studies in the Chinese Economy 22).

Brenner, Mark (2001) "Re-examining the Distribution of Wealth in Rural China” In Riskin, Carl, Renwei, Zhao, Shi Li (Eds) China's Retreat from Equality: Income Distribution and Economic Transformation, Armonk, New York: M.E. Sharpe.

China's Yearbook of Ethnic Works, 2003. Beijing

Du, Yang, Park, Albert, Wang Sangui (2005) “Migration and Rural Poverty in China”, Journal of Comparative Economics, 33, 688 - 709.

Gustafsson, B and Li S (2003) "The Ethnic Minority - Majority Income Gap in Rural China during Transition”, Economic Development and Cultural Change, 51, (4), 805 - 822. 2003

Hannum, Emily \& Yu Zie (1998) "Ethnic Stratification in Northwest China: Occupational Differences Between Han Chinese and National Minorities in Xinjiang, 1982 - 1990”, Demography, 35, 323 - 333.

Heberer, Thomas (2005) "Ethnic Entrepreneurship and Ethnic Identity: A Case Study among the Liangshan Yi (Nuosu) in China”, China Quarterly, 407 - 427.

Hoy, Caroline and Qiang, Ren (2003) "Socioeconomic Impact of Uygur Movement to Beijing” pages 155 - 174 in Iredale, Robyn, Bilik, Naran and Guo, Fei (Eds) China's Minorities on the Move. Selected Case Studies, Armonk, New Yourk, London, England: M.E. Sharpe.

Hu, Tsui Yen (2003) "Uygur Movements Within Xinjiang and Its Ethnic Identity and Cultural Implications” pages 123 - 138 in Iredale, Robyn, Bilik, Naran and Guo, Fei (Eds) China's Minorities on the Move. Selected Case Studies, Armonk, New Yourk, London, England: M.E. Sharpe.

Iredal, Robyn, Bilik, Naran, Su, Wang with contributions from Guo, Fei and Hoy, Caroline (2001) Contemporary Minority Migration, Education and Ethnicity in China, Chelterhan, U.K., Northampton, MA U.S.A, Edward Elgar.

Knight, John and Li Shi (1997) "Cumulative Causation and Inequality among Villages in China”, Oxford Development Studies, Vol. 25, No. 2.

Li Shi, Luo Chuliang, Wei Zhong and Yue Ximing (2006) "Appendix. The 1995 and 2002 Household Surveys: Sampling Methods and Data Description” in Gustafsson, B., Li, S and Sicular, T. (eds) (2006). Inequality and Public Policy in China, Cambridge: Cambridge University Press (Forthcoming).

Longworth, John, Brown, Collin \& Williamson, Gregory (1997) "Second generation’ Problems Associated with Economic Reform in the Pastoral Region of China" International Journal of Social Economics, 24, 139 - 159. 
Mackerras, Colin, (1995) China's Minorities: Integration and Modernization in the Twentieth Century, Hong Kong: Oxford University Press, 1995.

Mackerras, Colin, (1998) "The Impact of Economic Reform on China’s Minority Nationalities”, Journal of the Asia Pacific Economy, 3, 61 - 79.

Mackerras, Colin (2003) China's Ethnic Minorities and Globalization, London: Routledge Curzon.

McKinley, Terry (1996) The Distribution of Wealth in Rural China, Armonk, New York: M.E. Sharpe.

Sato, Hiroshi (2003) Growth of Market Relations in Post-reform China: A Micro-Analysis of Peasants, Migrants and Peasant Entrepreneurs. London and New Youk: RoutledgeCurzon.

Sato, Hiroshi (2006) "The Impact of Village-Specific Factors on Household Income in Rural China” Chapter 12 in Gustafsson, B., Li, S and Sicular, T. (eds) (2006). Inequality and Public Policy in China, Cambridge: Cambridge University Press (Forthcoming) .

Zhao Renwei and Ding Sai (2006) "The Distribution of Wealth in China”, Chapter 5 in Gustafsson, B., Li, S and Sicular, T. (eds) (2006). Inequality and Public Policy in China, Cambridge: Cambridge University Press (Forthcoming). 


\section{Table 1}

The ten largest ethnic minorities in rural China according to the Census of 2000.

\begin{tabular}{|c|c|c|c|c|c|c|}
\hline & $\begin{array}{l}\text { Number } \\
\text { (millions) }\end{array}$ & $\begin{array}{l}\text { Urbanisation } \\
\text { rate }^{x}\end{array}$ & $\begin{array}{l}\text { Dominating } \\
\text { language. } \\
\text { (Type of } \\
\text { characters) }\end{array}$ & $\begin{array}{l}\text { Name of the } \\
\text { minority in } \\
\text { their own } \\
\text { language }\end{array}$ & $\begin{array}{l}\text { Dominating } \\
\text { religion }\end{array}$ & $\begin{array}{l}\text { Geographic } \\
\text { concentration }\end{array}$ \\
\hline Zhung & 12.6 & 22 & $\begin{array}{l}\text { Has own language } \\
\text { and written } \\
\text { language. The } \\
\text { language is divided } \\
\text { into south and } \\
\text { north macro } \\
\text { dialect areas and } \\
\text { in twelve micro } \\
\text { dialect areas. }\end{array}$ & $\begin{array}{l}\text { “Turen” or } \\
\text { “Bu } \\
\text { Zhuang” }\end{array}$ & Aboriginal religion & $\begin{array}{l}\text { Guangxi, Yunnan, } \\
\text { Guangdong and } \\
\text { Guizhou }\end{array}$ \\
\hline Miao & 7.7 & 14 & $\begin{array}{l}\text { Has own language } \\
\text { but no written } \\
\text { language. }\end{array}$ & $\begin{array}{l}\text { “Guo } \\
\text { Xiong”, } \\
\text { “Mu”, or } \\
\text { “Meng” }\end{array}$ & $\begin{array}{l}\text { Miao's religion is } \\
\text { complicated. They } \\
\text { have nature } \\
\text { worship, totem } \\
\text { worship, spirit } \\
\text { worship, ancestor } \\
\text { worship. Some are } \\
\text { Christian }\end{array}$ & $\begin{array}{l}\text { Guizhou, Hunan, } \\
\text { Yunnan, } \\
\text { Chongqing, } \\
\text { Guangxi, Hubei, } \\
\text { Sichuan and } \\
\text { Hainan. }\end{array}$ \\
\hline $\mathrm{Yi}$ & 7.0 & 10 & $\begin{array}{l}\text { Has own language } \\
\text { andwritten } \\
\text { language. }\end{array}$ & $\begin{array}{l}\text { “Nuo } \\
\text { Supo”, “Na } \\
\text { Supo” or } \\
\text { “Nie Supo” }\end{array}$ & $\begin{array}{l}\text { They have the } \\
\text { religion of "Bi } \\
\text { Muo" whose core } \\
\text { is ancestor worship } \\
\text { and gathered } \\
\text { nature worship, } \\
\text { totem worship, } \\
\text { spirit worship etc. }\end{array}$ & $\begin{array}{l}\text { Sichuan, Yunnan, } \\
\text { Guizhou and } \\
\text { Guangxi. }\end{array}$ \\
\hline Manchu & 6.9 & 35 & $\begin{array}{l}\text { Has own language } \\
\text { and written } \\
\text { language }\end{array}$ & Manchu & “Sa Man" religion & $\begin{array}{l}\text { Liaoning, Jilin, } \\
\text { Helongjiang, } \\
\text { Hebei, Beijing, } \\
\text { Tianjin, Shanghai, } \\
\text { Xian, Shandong, } \\
\text { Ningxia, Inner } \\
\text { Mongolia and } \\
\text { Xinjiang. }\end{array}$ \\
\hline Uyghur & 6.8 & 19 & $\begin{array}{l}\text { Has own language } \\
\text { and written } \\
\text { language }\end{array}$ & Uyghur & Islam & $\begin{array}{l}\text { Xinjiang especially } \\
\text { in south of Xinjiang }\end{array}$ \\
\hline Tuija & 6.6 & 18 & Has own language & “Bi Zika”, & Ancestor worship & Hunan, Hubei, \\
\hline
\end{tabular}




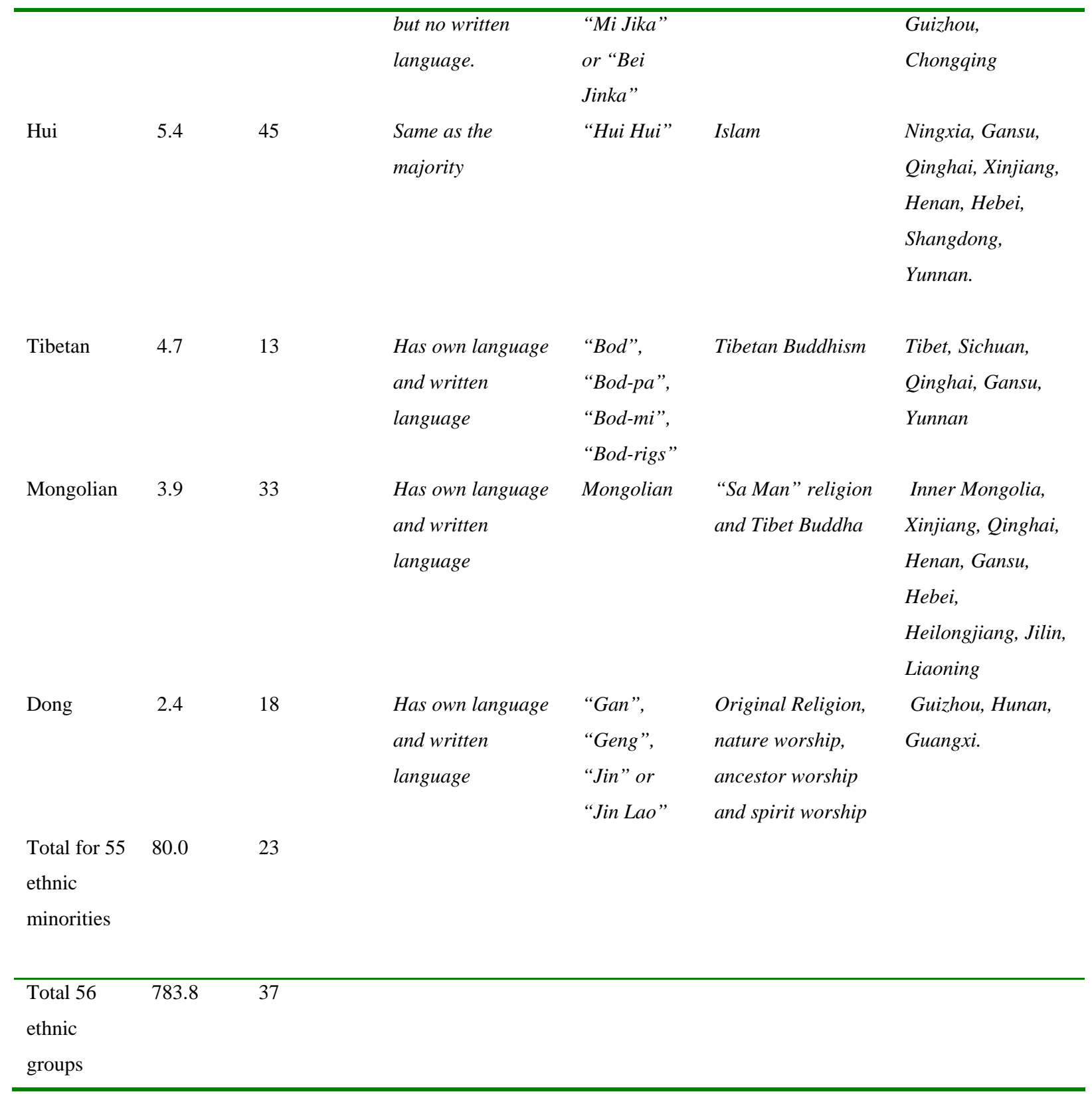

Source: China's Yearbook of Ethnic Works, 2003

Note: The urbanisation rate is defined as: urban population / total population * 100 . 
Table 2

Villages surveyed for 2002 by province level unit and ethnic category

The Distribution of Villages

\begin{tabular}{|c|c|c|c|c|c|c|c|c|c|c|}
\hline \multirow[t]{2}{*}{ Province level unit } & \multirow{2}{*}{ Total } & \multirow{2}{*}{ Majority } & \multirow[t]{2}{*}{ Minority } & \multirow[b]{2}{*}{ Manchu } & \multirow[b]{2}{*}{ Hui } & \multirow[b]{2}{*}{ Uygur } & \multirow[b]{2}{*}{ Other } & \multirow[b]{2}{*}{ Zhuang } & \multirow[b]{2}{*}{ Miao } & \multirow[b]{2}{*}{$\mathrm{Yi}$} \\
\hline & & & & & & & & & & \\
\hline Beijing & 15 & 15 & & & & & & & & \\
\hline Hebei & 28 & 27 & 1 & & 1 & & & & & \\
\hline Shanxi & 38 & 38 & & & & & & & & \\
\hline Liaoning & 43 & 19 & 24 & 19 & 1 & & 4 & & & \\
\hline Jilin & 48 & 47 & 1 & 1 & & & & & & \\
\hline Jiangsu & 41 & 41 & & & & & & & & \\
\hline Zhejiang & 51 & 51 & & & & & & & & \\
\hline Anhui & 42 & 42 & & & & & & & & \\
\hline Jiangxi & 43 & 43 & & & & & & & & \\
\hline Shandong & 59 & 59 & & & & & & & & \\
\hline Henan & 49 & 49 & & & & & & & & \\
\hline Hubei & 49 & 49 & & & & & & & & \\
\hline Hunan & 44 & 35 & 9 & & & & 7 & & 2 & \\
\hline Guangdong & 53 & 53 & & & & & & & & \\
\hline Guangxi & 38 & 22 & 16 & & & & & 16 & & \\
\hline Chongqing & 20 & 20 & & & & & & & & \\
\hline Sichuan & 49 & 48 & 1 & & & & & & & 1 \\
\hline Guizhou & 40 & 15 & 25 & & & & 12 & & 10 & 3 \\
\hline Yunnan & 26 & 7 & 19 & & 1 & & 12 & & & 6 \\
\hline Shanxi & 36 & 36 & & & & & & & & \\
\hline Gansu & 26 & 26 & & & & & & & & \\
\hline Xinjiang & 69 & 14 & 55 & & 5 & 50 & & & & \\
\hline Sum & 907 & 756 & 151 & 20 & 8 & 50 & 35 & 16 & 12 & 10 \\
\hline
\end{tabular}

Source: Village Survey 
Table 3: Basic information on the villages surveyed

\begin{tabular}{|c|c|c|c|c|c|c|c|c|c|c|}
\hline & Total & Majority & Minority & Manchu & Hui & Uygur & Other & Zhuang & Miao & $\mathrm{Yi}$ \\
\hline \multicolumn{11}{|c|}{ Geographic conditions (\%) } \\
\hline Plain & 48.7 & 49.3 & 46.0 & 50.0 & 75.0 & 100.0 & 8.6 & & & \\
\hline Hilly area & 29.9 & 33.5 & 11.3 & 10.0 & & & 20.0 & 53.3 & & \\
\hline Mountains & 21.4 & 17.2 & 42.7 & 40.0 & 25.0 & & 71.4 & 46.7 & 100.0 & 100.0 \\
\hline $\begin{array}{l}\text { The village in } \\
\text { poor area/total } \\
\text { village } \\
\text { number (\%) }\end{array}$ & 32.5 & 29.4 & 48.3 & 0 & 25.0 & 24.0 & 60.0 & 100.0 & 100.0 & 100.0 \\
\hline \multicolumn{11}{|c|}{ Introduction of electricity (\%) } \\
\hline Before 1969 & 27.6 & 29.8 & 16.5 & 55.0 & 12.5 & 2.0 & 28.6 & 12.5 & & \\
\hline 1970-1979 & 35.5 & 36.4 & 30.5 & 45.0 & 37.5 & 32.0 & 28.6 & 25.0 & 16.7 & 20.0 \\
\hline 1980-1989 & 26.7 & 25.8 & 31.1 & & 37.5 & 34.0 & 34.3 & 25.0 & 50.0 & 50.0 \\
\hline $1990-1998$ & 7.5 & 6.8 & 11.3 & & 12.5 & 12.0 & 5.7 & 18.7 & 25.0 & 20.0 \\
\hline After 1999 & 2.5 & 1.2 & 9.3 & & & 20.0 & 2.8 & 12.5 & & 10.0 \\
\hline Not yet & 0.2 & & 1.3 & & & & & 6.3 & 8.3 & \\
\hline $\begin{array}{l}\text { Distance from } \\
\text { nearest county } \\
\text { seat }(\mathrm{km})\end{array}$ & 24.5 & 22.4 & 34.8 & 29.3 & 23.2 & 29.2 & 45.8 & 48.8 & 23.0 & 37.3 \\
\hline $\begin{array}{l}\text { Distance from } \\
\text { nearest } \\
\text { transportation } \\
\text { terminal (bus } \\
\text { terminals, } \\
\text { train stations, } \\
\text { or wharfs) } \\
(\mathrm{km})\end{array}$ & 5.4 & 4.9 & 7.7 & 2.6 & 4.5 & 7.4 & 6.9 & 7.5 & 7.0 & 25.8 \\
\hline $\begin{array}{l}\text { Number of } \\
\text { observations }\end{array}$ & 907 & 756 & 151 & 20 & 8 & 50 & 35 & 16 & 12 & 10 \\
\hline $\begin{array}{l}\text { Average } \\
\text { population } \\
\text { size }\end{array}$ & 1831 & 1827 & 1853 & 1654 & 2417 & 1346 & 1679 & 3881 & 1283 & 2377 \\
\hline Province & & $\begin{array}{l}22 \\
\text { provinces }\end{array}$ & $\begin{array}{l}\text { Heibei, } \\
\text { Liaoning } \\
\text {, Jilin, } \\
\text { Hunan, } \\
\text { Guangxi, } \\
\text { Sichuan, } \\
\text { Guizhou, } \\
\text { Yunnan, } \\
\text { Xinjiang }\end{array}$ & $\begin{array}{l}\text { Liaoning, } \\
\text { Jilin }\end{array}$ & $\begin{array}{l}\text { Hebei, } \\
\text { Liaoning, } \\
\text { Yunnan, } \\
\text { Xinjiang }\end{array}$ & Xinjiang & $\begin{array}{l}\text { Liaoning, } \\
\text { Hunan, } \\
\text { Guizhou, } \\
\text { Yunnan }\end{array}$ & Guangxi & $\begin{array}{l}\text { Hunan, } \\
\text { Guizhou }\end{array}$ & $\begin{array}{l}\text { Sichuan, } \\
\text { Guizhou, } \\
\text { Yunnan }\end{array}$ \\
\hline
\end{tabular}

Note: the 22 provinces include: Beijing, Hebei, Shanxi, Liaoning, Jilin, Jiangsu, Zhejiang, Anhui, Jiangxi, Shandong, Henan, Hubei, Hunan, Guangdong, Guangxi, Chongqing, Sichuan, Guizhou, Yunnan, Shanxi, Gansu, Xinjiang.

An altitude of less than 200 meters above sea level is termed "Plains", an altitude of 200-500 meters above the sea level is classified as "Hilly" and "Mountains" have an altitude of more than 500 meters above sea level. Source: Village Survey 
Table 4: Average household per capita village income by ethnic category 2002

\begin{tabular}{|c|c|c|c|c|c|c|c|c|c|c|}
\hline & Total & Majority & Minority & Manchu & Hui & Uygur & Other & Zhuang & Miao & $\mathrm{Yi}$ \\
\hline $\begin{array}{l}\text { Net income } \\
\text { per capita in } \\
\text { the } \\
\text { village(Yuan) }\end{array}$ & 2456.68 & 2608.21 & 1698.07 & 3249.3 & 1948.61 & 1672.12 & 1327.91 & 1282.94 & 1230.55 & 1045.72 \\
\hline $\begin{array}{l}\text { Net income } \\
\text { per capita } \\
\text { index in the } \\
\text { village } \\
\text { Income } \\
\text { deciles }\end{array}$ & 100.0 & 106.2 & 69.1 & 132.3 & 79.3 & 68.1 & 54.1 & 52.2 & 50.1 & 42.6 \\
\hline 1 (lowest) & 90 & 49 & 41 & & & 14 & 12 & 5 & 5 & 5 \\
\hline 2 & 89 & 64 & 25 & & 1 & 6 & 9 & 5 & 2 & 2 \\
\hline 3 & 90 & 68 & 22 & & 3 & 6 & 5 & 2 & 4 & 2 \\
\hline 4 & 92 & 73 & 19 & & 1 & 6 & 6 & 4 & 1 & 1 \\
\hline 5 & 92 & 85 & 9 & & 1 & 6 & 2 & & & \\
\hline 6 & 97 & 89 & 7 & 4 & & 2 & 1 & & & \\
\hline 7 & 87 & 79 & 7 & 1 & & 6 & & & & \\
\hline 8 & 92 & 84 & 8 & 3 & 2 & 3 & & & & \\
\hline 9 & 91 & 80 & 11 & 10 & & 1 & & & & \\
\hline 10 (highest) & 87 & 85 & 2 & 2 & & & & & & \\
\hline $\begin{array}{l}\text { Number of } \\
\text { observations }\end{array}$ & 907 & 756 & 151 & 20 & 8 & 50 & 35 & 16 & 12 & 10 \\
\hline
\end{tabular}

Source: Village Survey 
Table 5: Average per capita household village wealth in by ethnic category 2002

\begin{tabular}{|c|c|c|c|c|c|c|c|c|c|c|c|}
\hline & $\begin{array}{c}\text { Total } \\
\text { wealth } \\
\text { (Yuan) }\end{array}$ & $\begin{array}{c}\text { Total } \\
\text { (Index } \\
\text { ) }\end{array}$ & $\begin{array}{c}\text { Majorit } \\
\mathrm{y}\end{array}$ & $\begin{array}{c}\text { Minorit } \\
\mathrm{y}\end{array}$ & $\begin{array}{c}\text { Manch } \\
\mathrm{u}\end{array}$ & Hui & $\begin{array}{c}\text { Uygu } \\
\text { r }\end{array}$ & $\begin{array}{c}\text { Othe } \\
r\end{array}$ & $\begin{array}{c}\text { Zhuan } \\
\text { g }\end{array}$ & $\begin{array}{c}\text { Mia } \\
0\end{array}$ & $\mathrm{Yi}$ \\
\hline $\begin{array}{c}\text { Total } \\
\text { wealth }\end{array}$ & $\begin{array}{c}13498.5 \\
8\end{array}$ & 100.0 & 104.4 & 77.8 & 141.9 & 84.6 & 85.1 & 59.4 & 50.7 & $\begin{array}{c}43 . \\
2\end{array}$ & $\begin{array}{c}56 . \\
8\end{array}$ \\
\hline Land & 4167.94 & 100.0 & 98.4 & 107.8 & 154.5 & $\begin{array}{c}127 . \\
9\end{array}$ & 138.1 & 83.1 & 46.4 & 54.7 & 95.7 \\
\hline $\begin{array}{c}\text { Financial } \\
\text { Assets }\end{array}$ & 1623.57 & 100.0 & 104.1 & 79.7 & 261.5 & 77.7 & 75.9 & 35.3 & 27.1 & 19.1 & 49.3 \\
\hline Housing & 5652.02 & 100.0 & 109.6 & 52.1 & 106.2 & 53.2 & 39.6 & 44.5 & 60.5 & 40.0 & 33.6 \\
\hline $\begin{array}{l}\text { Consumer } \\
\text { Goods }\end{array}$ & 790.91 & 100.0 & 111.0 & 45.2 & 116.5 & 19.8 & 5.7 & 69.2 & 59.6 & 36.8 & 23.3 \\
\hline $\begin{array}{l}\text { Capital } \\
\text { Assets }\end{array}$ & 1264.14 & 100.0 & 97.7 & 111.5 & 121.9 & $\begin{array}{c}132 . \\
1\end{array}$ & 175.8 & 72.5 & 45.5 & 54.4 & 62.4 \\
\hline Debts & 163.34 & 100.0 & 108.0 & 60.3 & 156.5 & 66.8 & 8.7 & 76.2 & 40.7 & 89.0 & 62.0 \\
\hline Net Wealth & $\begin{array}{c}13335.2 \\
5\end{array}$ & 100.0 & 104.4 & 78.0 & 141.7 & 84.9 & 86.1 & 59.2 & 50.8 & 42.6 & 56.7 \\
\hline \multicolumn{12}{|l|}{$\begin{array}{l}\text { Wealth } \\
\text { deciles }\end{array}$} \\
\hline 1 (lowest) & & 91 & 60 & 31 & & 1 & 2 & 14 & 4 & 7 & 3 \\
\hline 2 & & 91 & 70 & 21 & & & 6 & 4 & 6 & 3 & 2 \\
\hline 3 & & 91 & 72 & 19 & & & 7 & 5 & 4 & 1 & 2 \\
\hline 4 & & 90 & 80 & 10 & & 1 & 6 & 1 & & & 2 \\
\hline 5 & & 91 & 75 & 16 & 1 & 2 & 7 & 4 & 1 & 1 & \\
\hline 6 & & 91 & 78 & 13 & & 1 & 7 & 4 & 1 & & \\
\hline 7 & & 90 & 82 & 8 & & 2 & 4 & 2 & & & \\
\hline 8 & & 91 & 72 & 19 & 10 & & 7 & 1 & & & 1 \\
\hline 9 & & 91 & 83 & 8 & 5 & 1 & 2 & & & & \\
\hline $\begin{array}{c}10 \\
\text { (highest) }\end{array}$ & & 90 & 84 & 6 & 4 & & 2 & & & & \\
\hline $\begin{array}{l}\text { Number of } \\
\text { observatio } \\
\text { ns }\end{array}$ & & 907 & 756 & 151 & 20 & 8 & 50 & 35 & 16 & 12 & 10 \\
\hline
\end{tabular}


Table 6: Villagers' perception of economic situation in 2002 by ethnic category

\begin{tabular}{|c|c|c|c|c|c|c|c|c|c|c|}
\hline & Total & Majority & Minority & Manchu & "Hui & 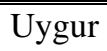 & Other & Zlhuang & Miao & $\overline{\mathrm{Yi}}$ \\
\hline \multicolumn{11}{|l|}{$\begin{array}{l}\text { Are you satisfied } \\
\text { with ...? }\end{array}$} \\
\hline $\begin{array}{l}\text { The income of your } \\
\text { household) }\end{array}$ & 3.01 & 3.00 & 3.06 & 2.78 & 3.21 & $2.58 *$ & $3.52 *$ & $3.65 *$ & 3.10 & $3.39 *$ \\
\hline $\begin{array}{l}\text { Lliving conditions } \\
\text { as a whole }\end{array}$ & 2.79 & 2.76 & $2.94 *$ & $2.49 *$ & 2.76 & 2.75 & $3.18^{*}$ & $3.45^{*}$ & 2.91 & $3.40^{*}$ \\
\hline Amount of food & 1.10 & 1.09 & $1.17^{*}$ & 1.03 & 1.08 & $1.16^{*}$ & $1.19 *$ & $1.29 *$ & $1.24 *$ & $1.20 *$ \\
\hline $\begin{array}{l}\text { Your ability to } \\
\text { meet financial } \\
\text { needs. }\end{array}$ & 1.40 & 1.38 & $1.52^{*}$ & $1.24^{*}$ & 1.38 & $1.53^{*}$ & $1.52^{*}$ & $1.79 *$ & $1.59 *$ & $1.57^{*}$ \\
\hline $\begin{array}{l}\text { Your health? } \\
\text { Number of } \\
\text { observations }\end{array}$ & 2.03 & 2.02 & 2.06 & 1.95 & 2.24 & 1.94 & 2.11 & $2.31 *$ & 1.89 & $2.38^{*}$ \\
\hline
\end{tabular}

Note: All variables are tested between majority and minority, majority, and the six other ethnic groups. If it is significant, it has *. The answers are 1: very much; 2 : relatively much; 3:just so-so; 4:not very much; 5: not at all.

Table 7: Estimates of income and wealth functions

\begin{tabular}{|c|c|c|c|c|}
\hline & \multicolumn{4}{|c|}{$\begin{array}{c}\text { Dependent Variable: Income per capita or Wealth per } \\
\text { capita }\end{array}$} \\
\hline & \multicolumn{2}{|c|}{ Income Function } & \multicolumn{2}{|c|}{ Wealth Function } \\
\hline & Coefficient & $t$-value & Coefficient & $t$-value \\
\hline $\begin{array}{l}\text { Labour force engaged in manufacturing /total } \\
\text { population }\end{array}$ & 49.54 & 11.95 & 311.14 & 9.99 \\
\hline $\begin{array}{l}\text { Labour force engaged in construction/total } \\
\text { population }\end{array}$ & 6.19 & 1.02 & -115.79 & -2.54 \\
\hline Irrigated land per capita & 101.84 & 3.97 & 660.57 & 3.42 \\
\hline Vegetable areas per capita & 609.23 & 5.87 & 2416.4 & 3.10 \\
\hline $\begin{array}{l}\text { Value of the village productive fixed assets per } \\
\text { capita }\end{array}$ & 0.397 & 1.91 & 3.66 & 2.35 \\
\hline Education in years & 90.58 & 3.27 & 698.18 & 3.35 \\
\hline Daily wage for local labour in the village and town & 33.36 & 5.73 & 325.26 & 7.51 \\
\hline Average province income per capita & 0.694 & 17.38 & 2.30 & 7.66 \\
\hline Disasters in 2002 & -173.02 & -2.78 & -704.96 & -1.51 \\
\hline Hilly area & -181.94 & -2.53 & -2430.52 & -4.50 \\
\hline Mountainous area & -394.50 & -4.46 & -4080.48 & -6.15 \\
\hline Electricity available before 1969 & 349.63 & 1.78 & 3200.69 & 2.17 \\
\hline Electricity available before 1979 & 217.81 & 1.15 & 1951.58 & 1.37 \\
\hline Electricity available before 1989 & 95.66 & 0.51 & 1380.64 & 0.97 \\
\hline Electricity available before 1998 & 186.86 & 0.91 & 1010.41 & 0.65 \\
\hline Manchu & 511.16 & 2.58 & 3820.62 & 2.57 \\
\hline Hui & 190.26 & 0.62 & 700.75 & 0.3 \\
\hline Uyghur & -103.22 & -0.69 & 164.56 & 0.15 \\
\hline Other & 309.82 & 1.65 & 2581.23 & 1.83 \\
\hline Zhuang & -126.26 & -0.57 & -20.80 & -0.01 \\
\hline Miao & 13.56 & 0.05 & -565.67 & -0.29 \\
\hline $\mathrm{Yi}$ & 228.22 & 0.81 & 3468.27 & 1.64 \\
\hline Constant & -1041.89 & -3.87 & -5663.07 & -2.80 \\
\hline Adj-R ${ }^{2}$ & 0.6531 & & 0.4909 & \\
\hline$F$-value & 78.53 & & 40.70 & \\
\hline No. of observations & 907 & & 907 & \\
\hline
\end{tabular}


Table 8: Explanatory variables by ethnic category

\begin{tabular}{|c|c|c|c|c|c|c|c|c|c|c|}
\hline & Total & Majority & Minority & Manchu & Hui & Uygur & Other & Zhuang & Miao & $\mathrm{Yi}$ \\
\hline $\begin{array}{l}\text { Labour force } \\
\text { engaged in } \\
\text { manufacturing } \\
\text { /total population } \\
\text { (\%) }\end{array}$ & 5.4 & 6.0 & 2.3 & 2.7 & 0.6 & 0.2 & 4.3 & 2.3 & 4.2 & 1.5 \\
\hline $\begin{array}{l}\text { Labour force } \\
\text { engaged in } \\
\text { construction/total } \\
\text { population (\%) }\end{array}$ & 4.1 & 4.6 & 1.9 & 2.8 & 1.4 & 0.2 & 2.6 & 4.4 & 3.9 & 0.6 \\
\hline $\begin{array}{l}\text { Irrigated land per } \\
\text { capita (Mu) }\end{array}$ & 0.9 & 0.8 & 1.5 & 0.7 & 2.1 & 3.3 & 0.5 & 0.2 & 0.4 & 0.3 \\
\hline $\begin{array}{l}\text { Vegetable areas } \\
\text { per capita }(\mathrm{Mu})\end{array}$ & 0.18 & 0.18 & 0.15 & 0.37 & 0.03 & 0.09 & 0.17 & 0.09 & 0.14 & 0.07 \\
\hline $\begin{array}{l}\text { Value of the } \\
\text { village productive } \\
\text { fixed assets per } \\
\text { capita (Yuan) }\end{array}$ & 15.9 & 16.2 & 13.9 & 38.9 & 0.04 & 23.0 & 4.7 & 0.1 & 0.01 & 0.5 \\
\hline Education Years & 6.8 & 6.9 & 6.2 & 7.9 & 7.0 & 5.7 & 6.0 & 6.5 & 5.5 & 5.3 \\
\hline $\begin{array}{l}\text { Daily wage for } \\
\text { local labour in the } \\
\text { village and town } \\
\text { (Yuan/day) }\end{array}$ & 17.7 & 18.1 & 16.1 & 19.9 & 15.3 & 16.0 & 14.9 & 15.1 & 17.0 & 15.1 \\
\hline $\begin{array}{l}\text { Average province } \\
\text { income per capita }\end{array}$ & 100.0 & 104.7 & 76.4 & 106.0 & 79.4 & 72.4 & 72.1 & 78.2 & 63.7 & 63.0 \\
\hline $\begin{array}{l}\text { Disasters in } 2002 \\
\text { (\%) }\end{array}$ & 50.8 & 48.3 & 63.3 & 70.0 & 75.0 & 76.0 & 82.9 & 75.0 & 100.0 & 100.0 \\
\hline Observations & 907 & 756 & 151 & 20 & 8 & 50 & 35 & 16 & 12 & 10 \\
\hline
\end{tabular}

Source: Village and household questionnaire

Average province income per capita in 2002 is from Statistic Yearbook of China 2003. 
Table 9: Results from simulation exercises

a): Income

\begin{tabular}{|c|c|c|c|c|c|c|c|c|c|c|}
\hline & Total & Majority & Minority & Manchu & Hui & Uygur & Other & Zhuang & Miao & YYi \\
\hline $\begin{array}{l}\text { Mean income per } \\
\text { capita in the } \\
\text { village (Yuan) }\end{array}$ & 2456.7 & 2608.2 & 1698.1 & 3249.3 & 1948.6 & 1672.1 & 1327.9 & 1282.9 & 1230.6 & 1045.7 \\
\hline $\begin{array}{l}\text { Predict mean } \\
\text { income per capita } \\
\text { based on sample } \\
\text { income for } \\
\text { categories (Yuan) }\end{array}$ & 2456.7 & $\begin{array}{c}2609.5 \\
(100.0)\end{array}$ & $\begin{array}{l}1691.8 \\
(100.0)\end{array}$ & $\begin{array}{l}2787.6 \\
(100.0)\end{array}$ & $\begin{array}{l}1772.6 \\
(100.0)\end{array}$ & $\begin{array}{l}1753.3 \\
(100.0)\end{array}$ & $\begin{array}{l}1456.9 \\
(100.0)\end{array}$ & $\begin{array}{l}1430.4 \\
(100.0)\end{array}$ & $\begin{array}{l}1273.1 \\
(100.0)\end{array}$ & $\begin{array}{c}872.3 \\
(100.0)\end{array}$ \\
\hline $\begin{array}{l}\text { Change one } \\
\text { variable at a time } \\
\text { to the average } \\
\text { level of rural } \\
\text { China }\end{array}$ & & & & & & & & & & \\
\hline $\begin{array}{l}\text { Labour force } \\
\text { engaged in } \\
\text { manufacturing } \\
\text { /total population } \\
\text { (\%) }\end{array}$ & & 98.8 & 108.9 & 104.7 & 113.3 & 114.7 & 103.6 & 110.6 & 93.9 & 121.9 \\
\hline $\begin{array}{l}\text { Labour force } \\
\text { engaged in } \\
\text { construction/total } \\
\text { population (\%) }\end{array}$ & & 99.9 & 100.7 & 100.3 & 100.8 & 101.2 & 100.6 & 99.9 & 100.0 & 102.2 \\
\hline $\begin{array}{l}\text { Irrigated land per } \\
\text { capita (Mu) }\end{array}$ & & 100.4 & 97.0 & 100.9 & 94.0 & 87.2 & 103.1 & 105.0 & 104.2 & 107.0 \\
\hline $\begin{array}{l}\text { Vegetable areas } \\
\text { per capita (Mu) }\end{array}$ & & 99.9 & 101.2 & 95.5 & 105.4 & 103.2 & 100.3 & 103.7 & 101.7 & 107.5 \\
\hline $\begin{array}{l}\text { Value of the } \\
\text { village productive } \\
\text { fixed assets per } \\
\text { capita (Yuan) }\end{array}$ & & 100.0 & 100.1 & 99.7 & 100.4 & 99.8 & 100.3 & 100.4 & 100.4 & 100.7 \\
\hline Education Years & & 99.5 & 103.6 & 96.2 & 99.2 & 106.1 & 105.3 & 102.0 & 109.8 & 116.8 \\
\hline $\begin{array}{l}\text { Daily wage for } \\
\text { local labour in the } \\
\text { village and town } \\
\text { (Yuan/day) }\end{array}$ & & 99.6 & 103.2 & 97.5 & 104.7 & 103.4 & 106.5 & 106.2 & 101.9 & 110.2 \\
\hline $\begin{array}{l}\text { Average province } \\
\text { income per capita } \\
\text { (Yuan) }\end{array}$ & & 96.8 & 124.4 & 96.2 & 120.4 & 127.7 & 133.6 & 126.8 & 149.9 & 174.4 \\
\hline Disasters in 2002 & & 99.9 & 101.4 & 99.4 & 101.2 & 98.6 & 104.7 & 104.5 & 106.6 & 105.9 \\
\hline $\begin{array}{l}\text { Hilly areas and } \\
\text { mountainous areas }\end{array}$ & & 99.7 & 102.6 & 101.1 & 97.4 & 93.0 & 111.9 & 108.3 & 116.2 & 124.6 \\
\hline $\begin{array}{l}\text { Electricity was } \\
\text { available before } \\
1969 \text { or before } \\
1979 \text { or before } \\
1989 \text { or before } \\
1998\end{array}$ & & 100.0 & 102.8 & 97.3 & 102.0 & 105.7 & 100.2 & 104.2 & 106.1 & 115.0 \\
\hline $\begin{array}{l}\text { Average } \\
\text { provincial income } \\
\text { and also altitude }\end{array}$ & & 96.5 & 127.0 & 97.3 & 117.8 & 120.7 & 145.5 & 135.1 & 166.1 & 199.0 \\
\hline
\end{tabular}

Note: Calculations based on Table 7 and Table 8 
b) Wealth

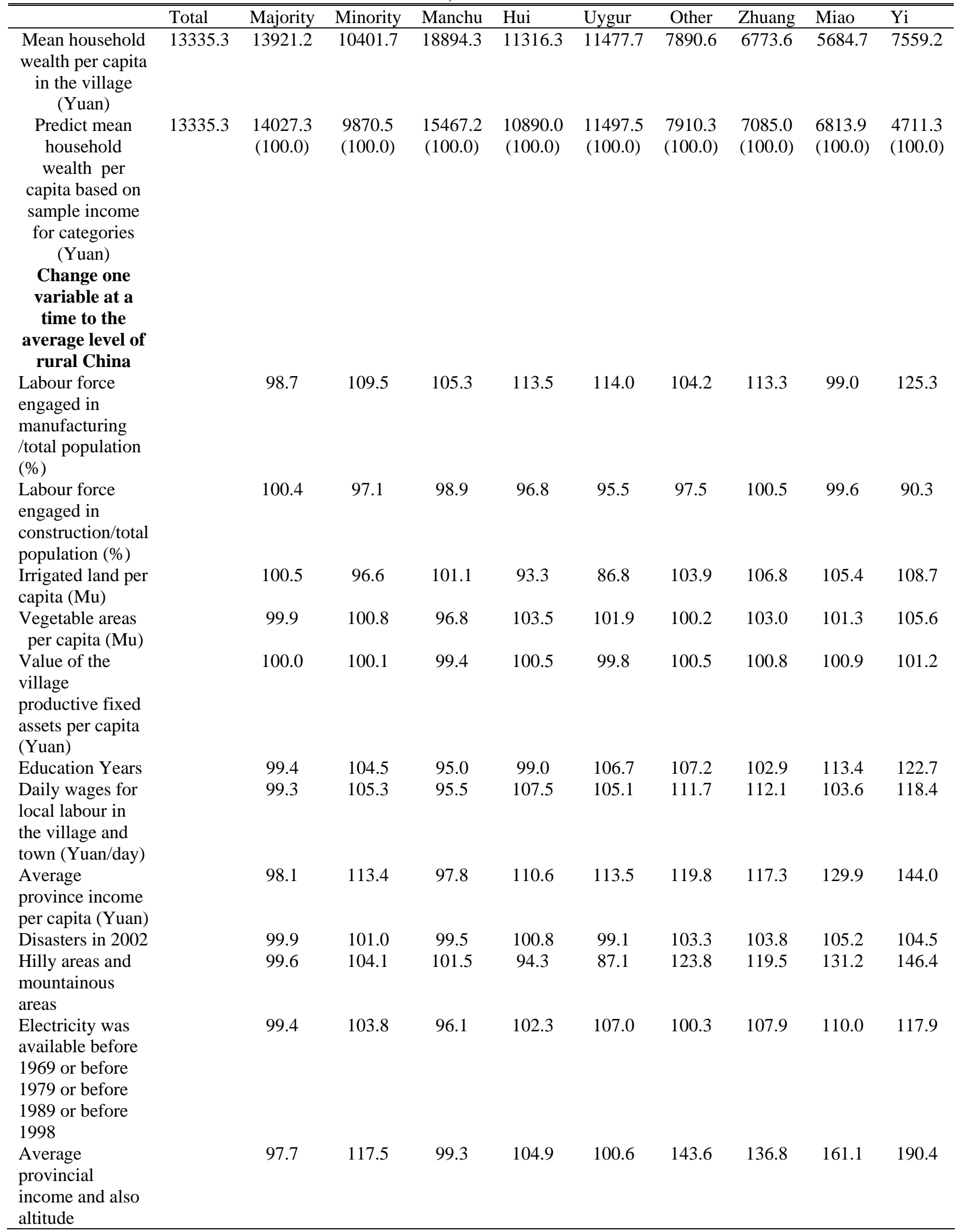


Table 10: Rates of out-migration 1998 and 2002 by ethnic category

\begin{tabular}{|c|c|c|c|c|c|c|c|c|c|c|}
\hline & Total & Majority & Minority & Manchu & "Hui & Uygur & Other & Z7huang & Miao & $\overline{\mathrm{Yi}}$ \\
\hline 1998 & & & & & & & & & & \\
\hline $\begin{array}{l}\text { Total number of out- } \\
\text { migration/total } \\
\text { population in village } \\
\text { (\%) }\end{array}$ & 8.4 & $9.0 *$ & $5.2^{*}$ & $2.7^{*}$ & $2.0 *$ & $0.8^{*}$ & 8.3 & $12.0 *$ & $13.6^{*}$ & $3.4 *$ \\
\hline $\begin{array}{l}\text { Number of out- } \\
\text { migration working } \\
\text { out of township } \\
\text { more than six } \\
\text { months/total } \\
\text { population (\%) }\end{array}$ & 6.1 & $6.6^{*}$ & $3.4^{*}$ & $1.7^{*}$ & $1.3^{*}$ & $0.3^{*}$ & 5.5 & 7.3 & $9.8^{*}$ & $1.9 *$ \\
\hline $\begin{array}{l}\text { Number of out- } \\
\text { migration working } \\
\text { out of the } \\
\text { province/total } \\
\text { population (\%) }\end{array}$ & 3.2 & $3.5^{*}$ & $2.0^{*}$ & $0.2^{*}$ & $0.1^{*}$ & $0^{*}$ & 3.5 & 4.3 & $7.4 *$ & 0.9 \\
\hline $\begin{array}{l}2002 \\
\text { Total number of out- } \\
\text { migration/total } \\
\text { population in village } \\
(\%)\end{array}$ & 10.9 & $11.6^{*}$ & $7.5^{*}$ & $4.3^{*}$ & $3.4^{*}$ & $1.3^{*}$ & 11.0 & $18.6^{*}$ & $16.9 *$ & 6.8 \\
\hline $\begin{array}{l}\text { Number of out- } \\
\text { migration working } \\
\text { out of township } \\
\text { more than six } \\
\text { months/total } \\
\text { population (\%) }\end{array}$ & 8.2 & $8.8^{*}$ & $5.2^{*}$ & $2.8^{*}$ & $2.7 *$ & $0.6^{*}$ & 7.8 & $12.3^{*}$ & $13.0^{*}$ & 4.5 \\
\hline $\begin{array}{l}\text { Number of out- } \\
\text { migration working } \\
\text { out of the } \\
\text { province/total } \\
\text { population (\%) }\end{array}$ & 4.6 & $4.9^{*}$ & $2.9 *$ & $0.5^{*}$ & $0.2^{*}$ & $0.1^{*}$ & 4.8 & $7.6^{*}$ & $10.0 *$ & 1.3 \\
\hline $\begin{array}{c}\text { Number of } \\
\text { Observations }\end{array}$ & 907 & 756 & 151 & 20 & 8 & 50 & 35 & 16 & 12 & 10 \\
\hline
\end{tabular}

Source: Village Survey.

Note) * indicates significance different to the Total at the 10 percent level. 
Table 11 Estimates of out-migration equations

\begin{tabular}{|c|c|c|c|c|}
\hline & \multicolumn{4}{|c|}{ Dependent Variable: Number of out-migration/total population } \\
\hline & \multicolumn{2}{|c|}{$\begin{array}{l}\text { Out-migration working out of } \\
\text { township }\end{array}$} & \multicolumn{2}{|c|}{$\begin{array}{c}\text { Out-migration working out of } \\
\text { province }\end{array}$} \\
\hline & Coefficient & $t$-value & Coefficient & $t$-value \\
\hline Net income per capita in the village in 1998 & -0.0009 & -3.18 & -0.0007 & -2.86 \\
\hline Average province income in 1998 & 0.0016 & 3.43 & -0.0007 & -1.85 \\
\hline Zhuang & 1.5716 & 0.83 & 0.5881 & 0.38 \\
\hline Hui & -4.0697 & -1.53 & -4.0797 & -1.91 \\
\hline Uygur & -6.5124 & -5.11 & -5.1205 & -4.99 \\
\hline $\mathrm{Yi}$ & -4.5308 & -1.86 & -5.0677 & -2.59 \\
\hline Miao & 3.7572 & 1.67 & 3.5461 & 1.96 \\
\hline Manchu & -3.6211 & -2.13 & -1.6031 & -1.17 \\
\hline Other & -0.7636 & -0.57 & -0.6429 & -0.59 \\
\hline Hilly area & 2.5241 & 4.08 & 1.6308 & 3.28 \\
\hline Mountainous area & 1.5606 & 2.03 & -0.7022 & -1.14 \\
\hline Electricity available before 1969 & -4.5699 & -2.73 & -3.6728 & -2.73 \\
\hline Electricity available before 1979 & -4.5017 & -2.78 & -2.5886 & -1.99 \\
\hline Electricity available before 1989 & -1.9640 & -1.21 & 0.0626 & 0.05 \\
\hline Electricity available before 1998 & -2.7928 & -1.58 & 0.1257 & 0.09 \\
\hline Irrigated land per capita in the village & -0.3112 & -1.42 & -0.5187 & -2.94 \\
\hline $\begin{array}{l}\text { The frequency of mutual-help during busy } \\
\text { season }\end{array}$ & -0.8988 & -2.46 & -0.4374 & -1.49 \\
\hline $\begin{array}{l}\text { The frequency of exchanged information of } \\
\text { employment }\end{array}$ & 1.5778 & 4.21 & 0.8653 & 2.87 \\
\hline $\begin{array}{l}\text { The frequency of mutual-help in weddings, } \\
\text { funerals, or other ceremonies }\end{array}$ & -0.9770 & -2.79 & -0.4358 & -1.55 \\
\hline Constant & 12.1907 & 4.85 & 10.7172 & 5.31 \\
\hline Adj- $R^{2}$ & 0.1660 & & 0.1877 & \\
\hline$F$-value & 10.49 & & 12.02 & \\
\hline No. of observations & 907 & & 907 & \\
\hline
\end{tabular}


Figure 1 Village characteristics by income deciles of villages (Source: Village and Household Survey)
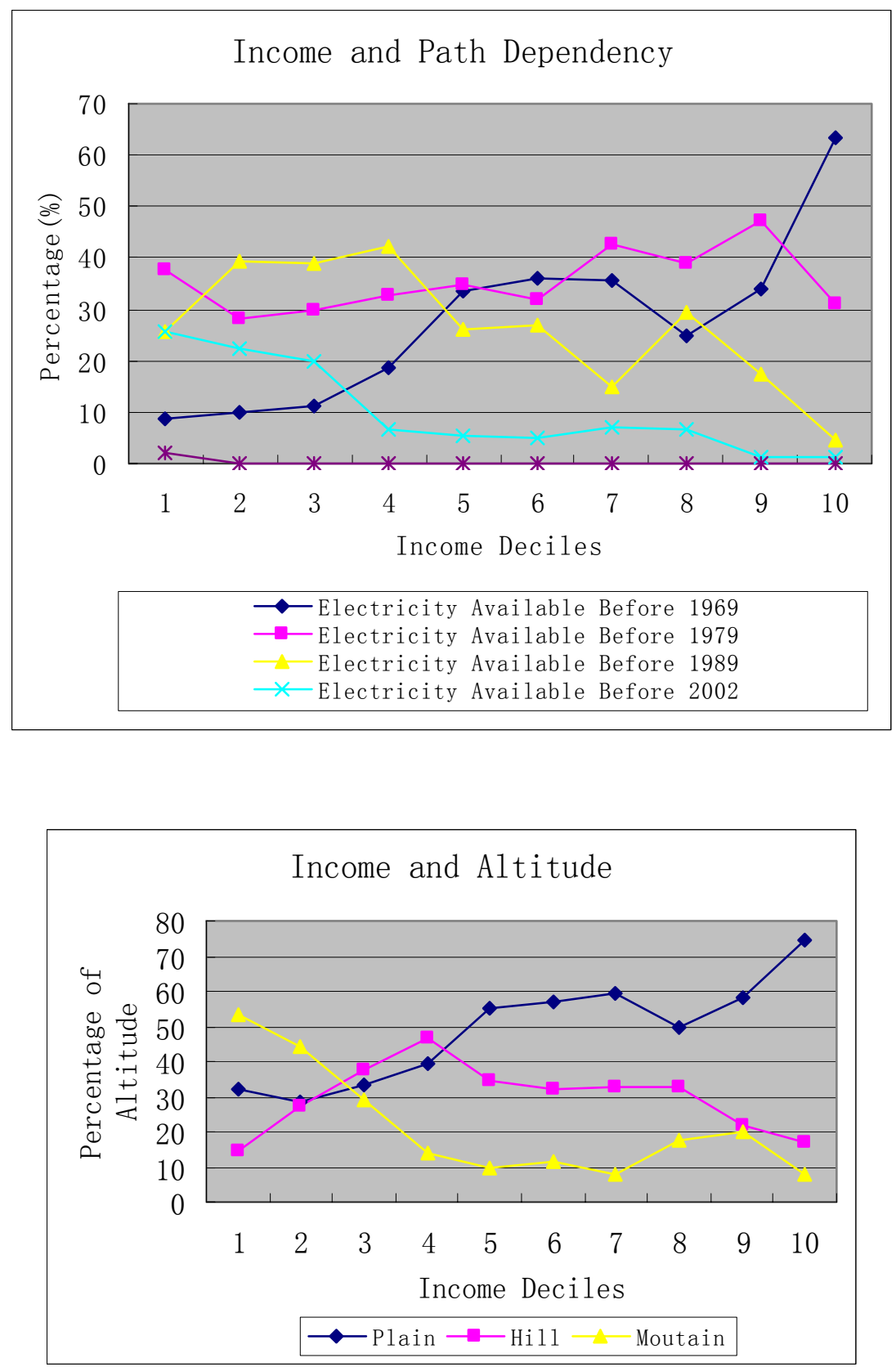

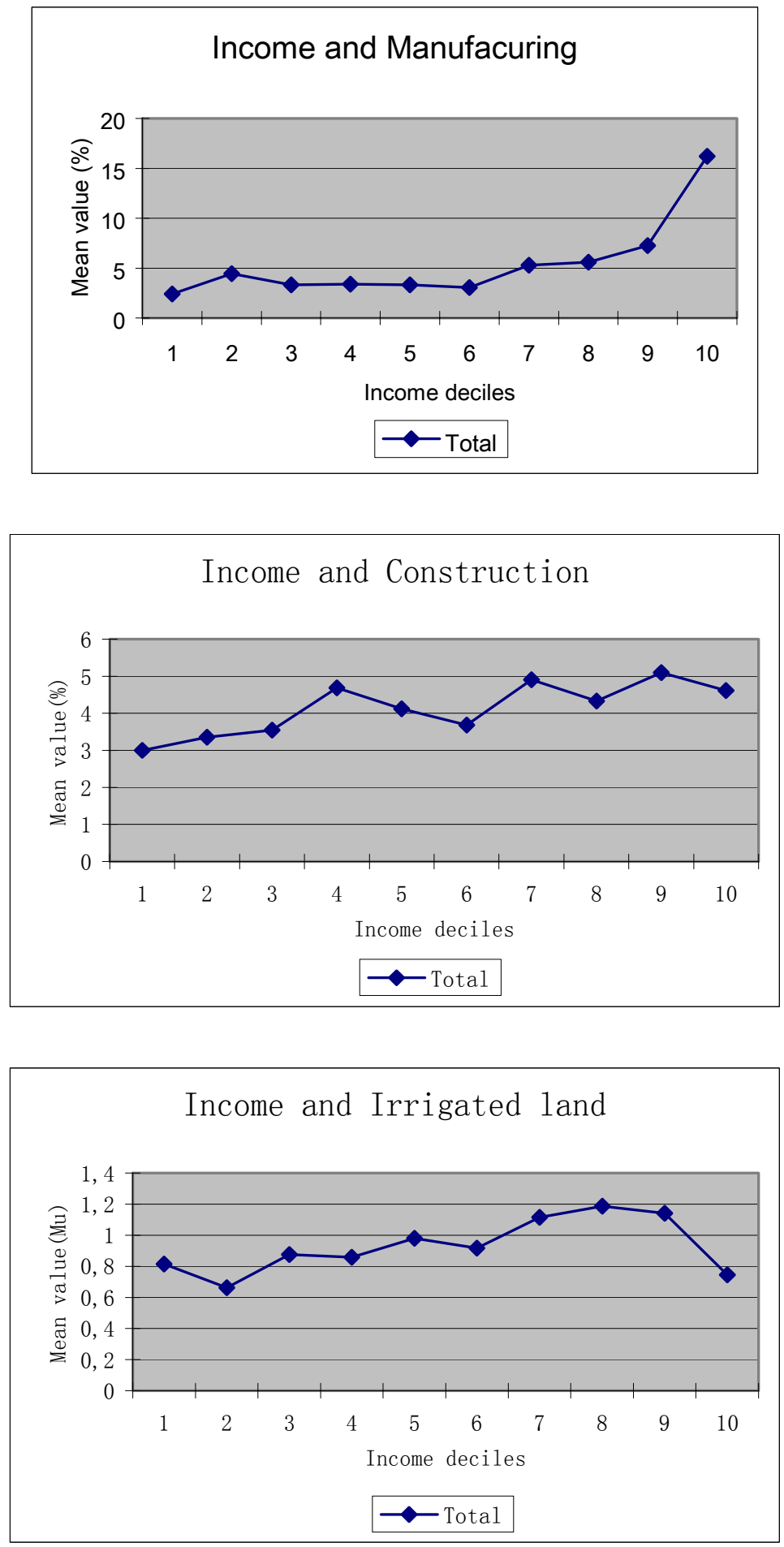

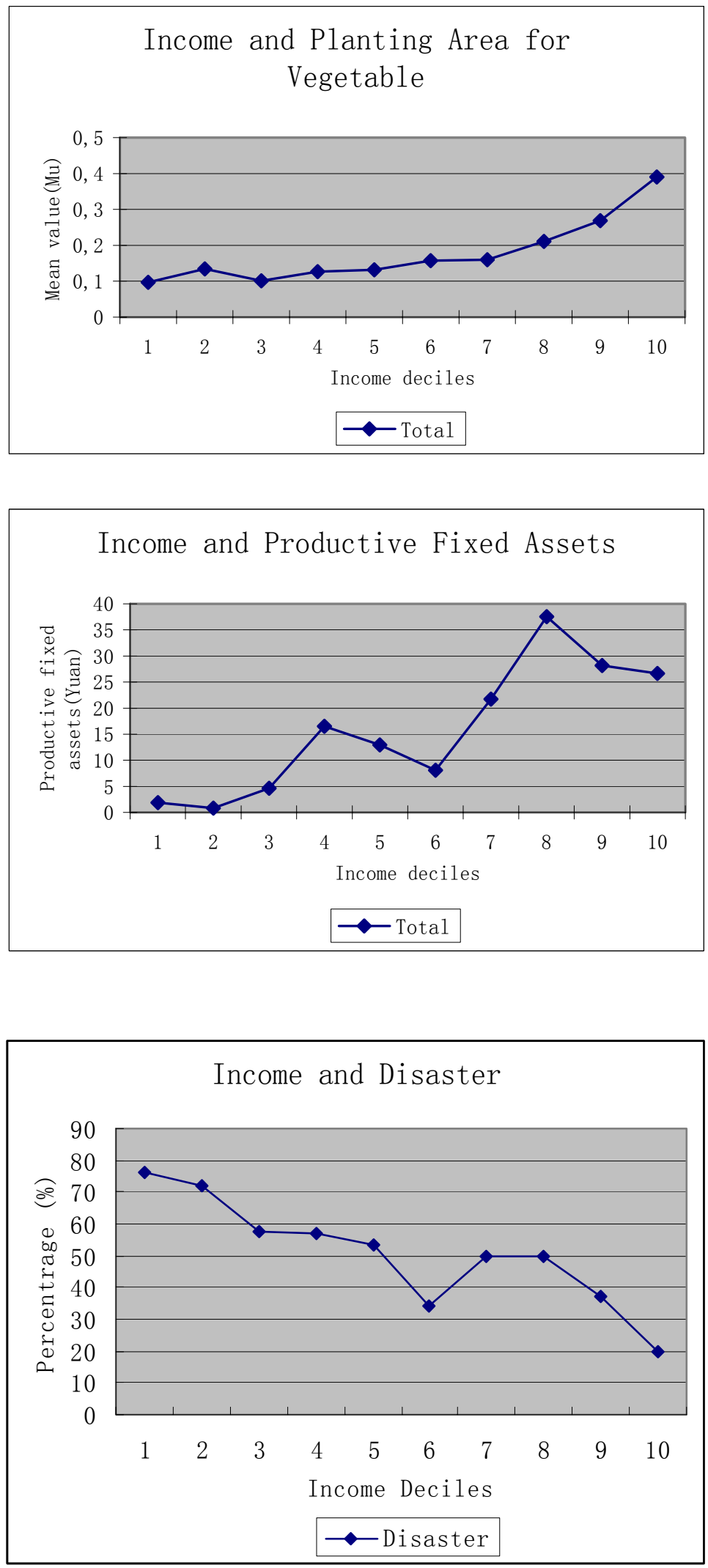

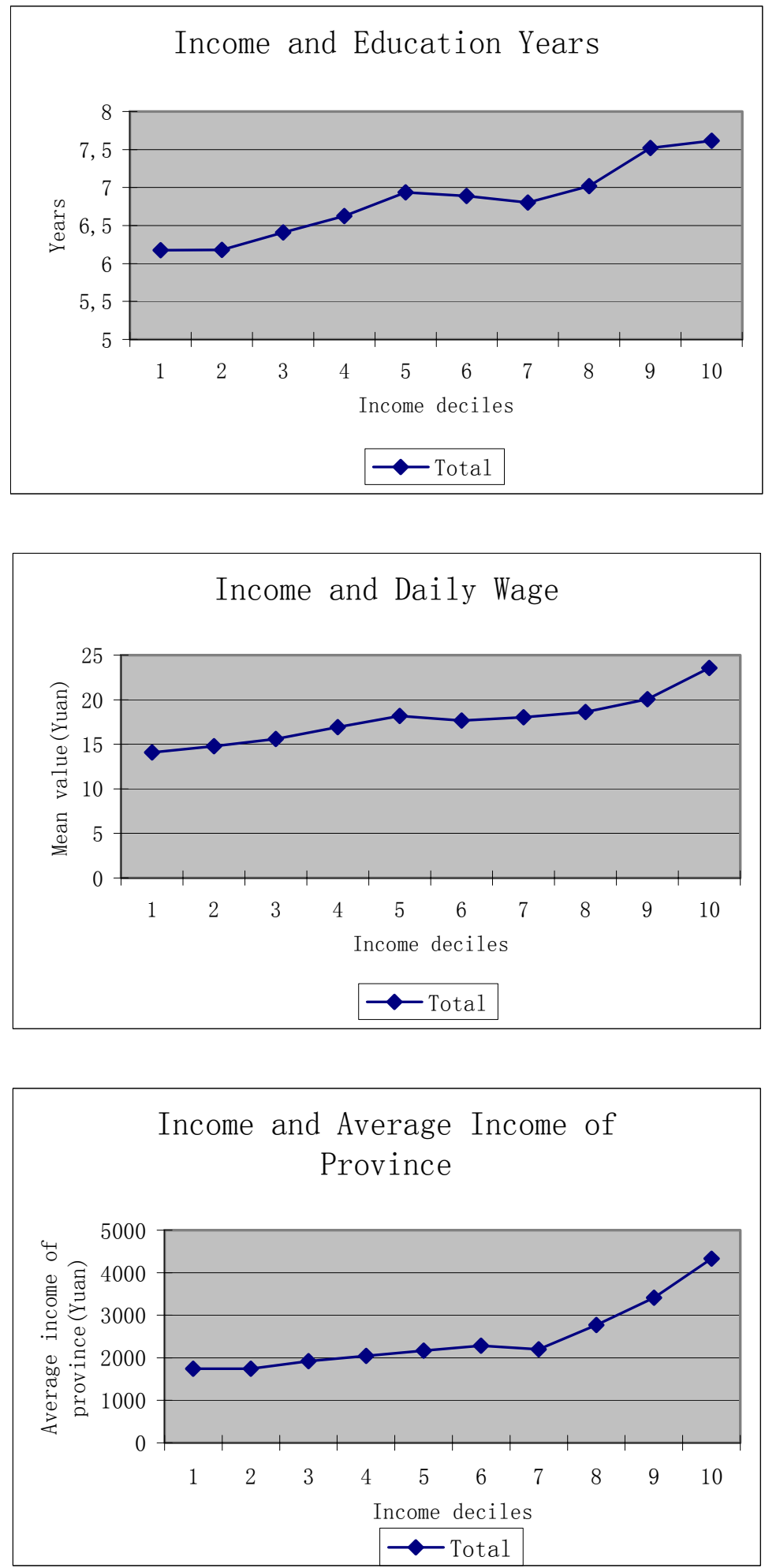
Figure 2 Out-migration rates 1998 and 2002 by income deciles of villages
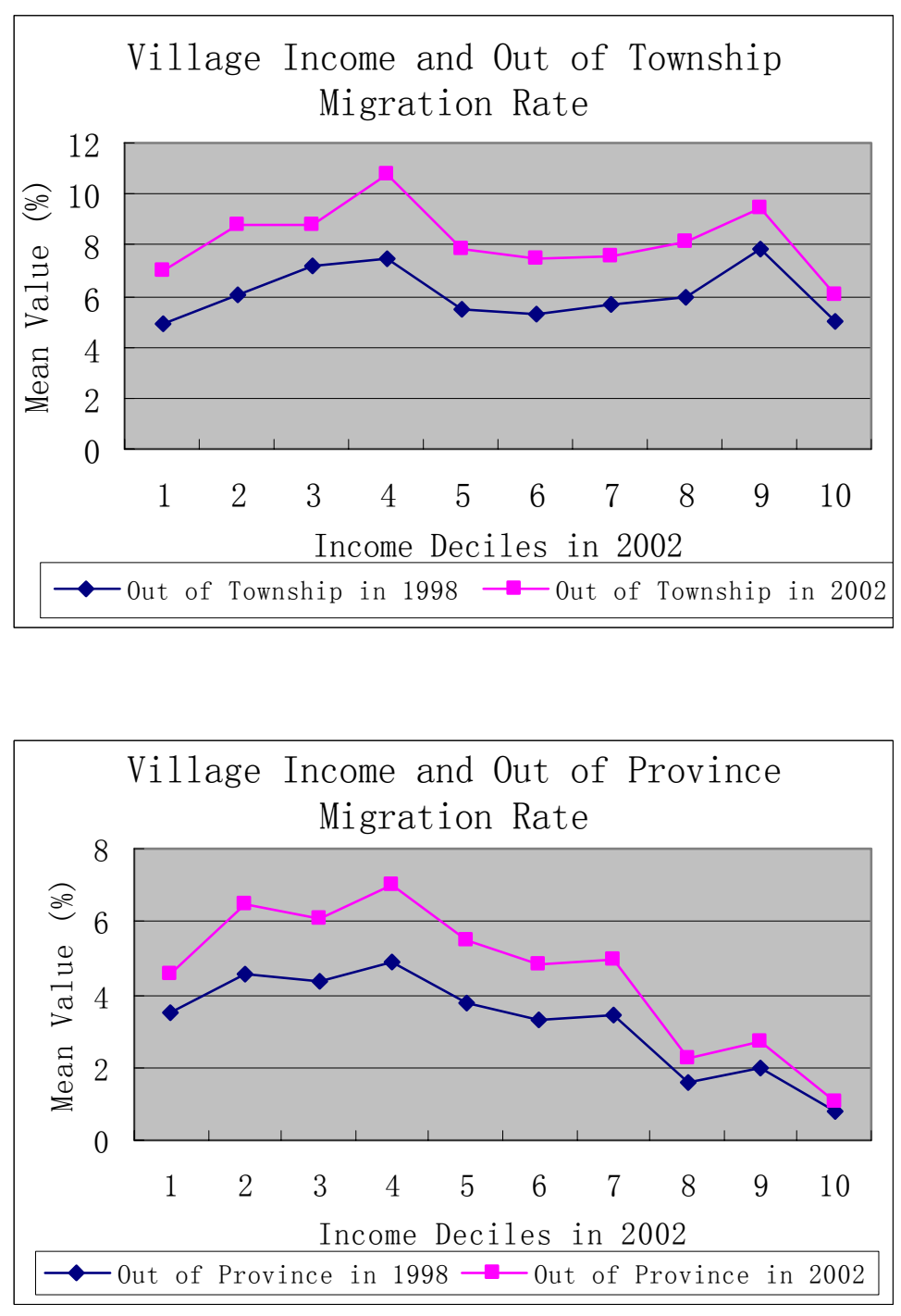